\title{
Homo Virtualis
}

Vol 3, No 1 (2020)

Human systems in time of COVID-19

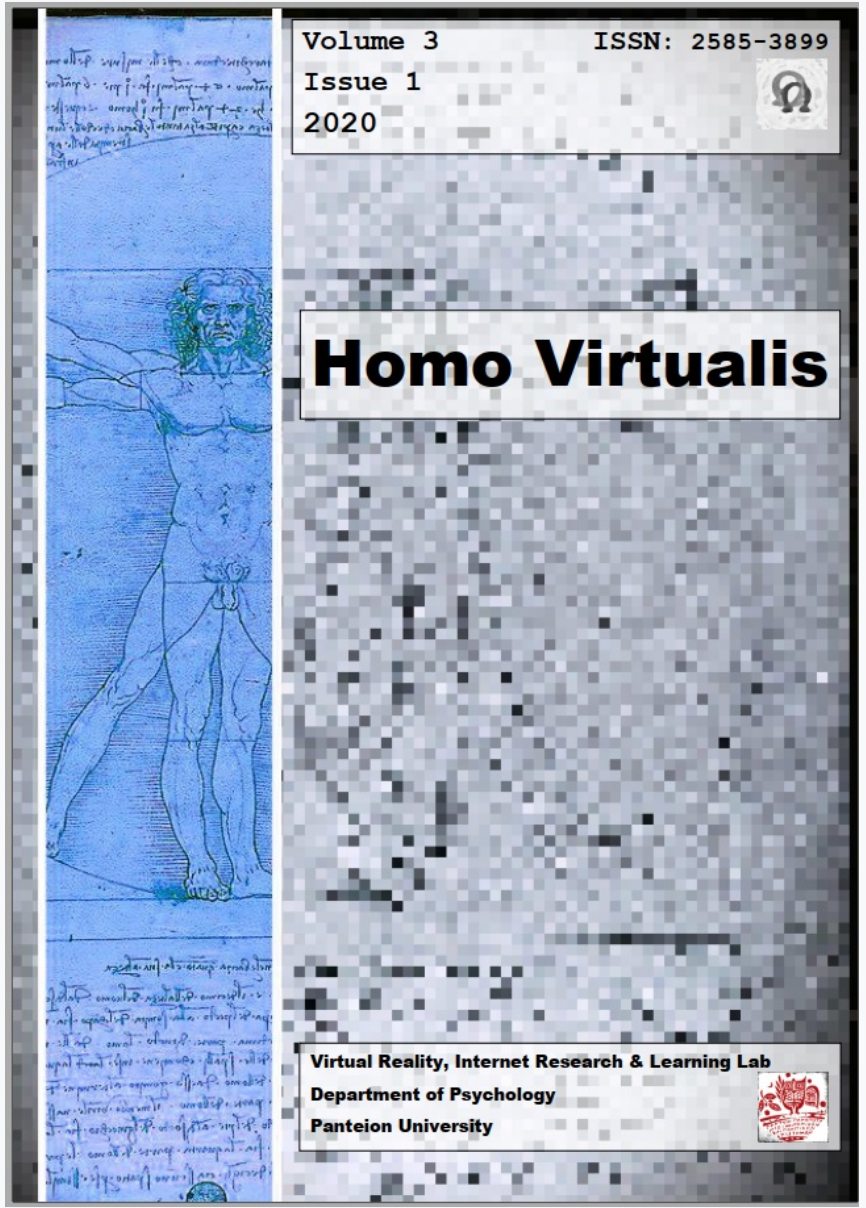

Psychosociology of Addiction and Rehabilitation: Construction of a Psychometric Instrument for screening problem and pathological gambling

Aikaterini Charonitaki, Irina Zhuravliova, Konstantinos Koskinas

doi: $10.12681 /$ homvir.23382

Copyright @ 2020, Aikaterini Charonitaki, Irina Zhuravliova, Konstantinos Koskinas

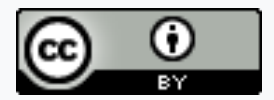

This work is licensed under a Creative Commons Attribution 4.0.

To cite this article:

Charonitaki, A., Zhuravliova, I., \& Koskinas, K. (2020). Psychosociology of Addiction and Rehabilitation: Construction of a Psychometric Instrument for screening problem and pathological gambling. Homo Virtualis, 3(1), 4-46.

https://doi.org/10.12681/homvir.23382 


\title{
Psychosociology of Addiction and Rehabilitation: Construction of a Psychometric Instrument for screening problem and pathological gambling
}

\section{Aikaterini Charonitaki ${ }^{1}$, Irina Zhuravliova ${ }^{2}$, Kostantinos Koskinas ${ }^{3}$}

\begin{abstract}
Gambling and gambling disorders have received solicitous attention by clinicians and researchers during the past three decades. The majority of existing psychometric instruments relevant to problem gambling are based on the clinical evaluation of symptomatology. The aim of this study was the development and evaluation of a self report instrument that comprehends elements based on three main factors: a. psychological, b. biological, c. sociological. In the first phase of this research, structured and semi-structured interview was conducted in 16 individuals. In the second phase, a pilot inventory that consisted of 227 items, was administered in 91 individuals of general population. In the last phase of this study participated 200 individuals from the community and completed the short form of the inventory that included 148 items. Factor analysis was conducted in all items and 115 statistically significant questions were derived which comprise the final form. The present instrument, which has demonstrated satisfactory psychometric properties, provides a first step in self evaluation of problem and pathological gambling in Greece and aims at effective counseling in order to reduce or even prevent addictive gambling behaviors.
\end{abstract}

Keywords: Pathological Gambling Behavior, Gambling Disorders, Pathological Gamblers, Problem Gamblers, Biological Factors, Psychological Factors, Sociological Factors

\footnotetext{
1 Post Doc Researcher in Laboratory of Social and Experimental Psychology, Panteion University. Adjunct Professor, School of Health and Welfare Services, Nursing Department, Hellenic Mediterranean University in Crete, Email: ha6eha@hotmail.com

2 Post Doc Researcher in Laboratory of Virtual Reality, Internet Research and E-Learning at the Dep of Psychology, Panteion University.

${ }^{3}$ Professor of Sociology and Director of the Laboratory of Virtual Reality, Internet Research and E-Learning at the Dep of Psychology (Panteion University).
} 


\section{Introduction}

Gambling is popular as a form of recreational activity and can be defined as placing something of value at risk in the hopes of gaining something of greater value (Potenza, 2006). The gambler seems to endanger something of value, in an outcome based on perceived luck (Potenza, et al., 2002). Types of gambling include betting on sporting events or numbers, cards, casinos, lotteries, etc.

The current literature describes a wide range of gambling-related behaviors. 80 to $85 \%$ of players engage in gambling on a social basis while the individual does not experience long-term or permanent problems related to gambling behavior. Problem gamblers continue gambling despite the problems that arise in their lives. This subcategory consists of players who lose more money than they intended to bet, spend a significant amount of time in the game or choose gambling as their main form of entertainment, often at the expense of other activities (e.g. choose to take a vacation in places where there are casinos, racetracks, etc.). This type of gambling may or may not meet the full criteria for the disorder (Blaszczynski, 2005)

Pathological Gambling is characterised by recurrent, excessive and destructive gambling regardless the various negative physiological, psychological and sociological consequences. In the fifth edition of diagnostic and statistical manual of mental disorders (DSM - IV; American Psychiatric Association, 1994), in order for an individual to be diagnosed as a pathological gambler must meet at least 5 out of 10 diagnostic criteria.

A systematic article review from 80 separate studies in 30 countries, refers that the worldwide prevalence of gambling is estimated at 1,5\% (Gowing et al., 2015).

This study is a methodological and empirical contribution. Therefore, the significance of the topic lies on the following facts:

1. Existing applications face the problem unilaterally and do not combine existing results sufficiently. There is a lack of studies on the problematic/ pathological gambling in the context of new trends and theoretical approaches (Titov et al., 2011).

2. Most psychometric tools relevant to problem gambling are based on the clinical evaluation of symptomatology while sufficiently innovative self-evaluation tools do not exist.

3. There are contradictions between the great need to implement preventive programs and the inadequacy of effective social protection and gambling addiction prevention systems/politics.

4. There is little use of data and information from different fields of knowledge that affect the occurrence of the problem and,

5. The elements that have a preventing influence on behavior to play responsibly in gambling have not been clearly clarified. 
Literature review has shown that pathological gamblers are an extremely heterogeneous group, while the basic factors that play crucial role in the development and maintenance of gambling behavior seem to be biological (e.g. biochemistry), psychological (e.g. personality, cognitions) and sociological.

Negative emotions are risk factors for the consequential development of problem gambling (Dickerson \& Baron, 2000; Hand, 1998). Individuals that have been diagnosed as problem gamblers at early age displayed negative emotions such as nervousness, anxiety, anger, victimization, low self - control in risk taking and impulsivity (Slutske et al., 2005).

Sensation seeking leads an individual to an irresistible urge to experience multiple, innovative and complex emotions through risk taking behaviors such as gambling (Coventry \& Brown, 1993). According to Dickerson (1979), pathological players gamble the last two minutes of permissible time and place more bets than social gamblers due to the fact that these situations act as reinforcement for the impulse and excitement that they look for. Sensation seeking might pertain to some sorts of gambling behavior (e.g. casino, illegal acts) (Dickerson, 1993; Coventry \& Brown, 1993).

Impulsivity seems to be a trait characteristic of pathological gamblers in relation to non-gamblers or social gamblers (Carlton \& Manowitz, 1994; Steel \& Blaszczynski, 1998; Petry, 2001). Impulsivity associates with an inability to postpone pleasure, an absence of an internalized value system that regulates individual's behavior, antisocial personality and disinhibition (McCormick et al., 1987; Blaszczynski et al., 1997; Blaszczynski \& Steel, 1998; Vitaro et al., 1999). Sensation seeking urges an individual to gamble while impulsivity leads to the continuum of this behavior regardless the long-term consequences (Zuckerman, 1999).

Pathological gamblers refer higher levels of impulsiveness in relation to non pathological gamblers (Nower et al., 2004; Blaszczynksi \& Steel, 1998) and general population, regardless substance abuse (Ledgerwood et al., 2009). Cognitive distortions are often present to pathological gamblers since they are possessed from a variety of cognitive beliefs (e.g. skill misperceptions, illusion of control, skewed temporal orientation, superstitious beliefs, selective memory and interpretative biases) that lead them to excessive gambling no matter the financial losses (Toneatto, 1999; Petry, 2001; Regard et al., 2003; Brand et al., 2005; Fuentes et al., 2006; Goudriaan et al., 2006; Kalechstein et al., 2007; Roca et al., 2008; Lawrence et al., 2009a, 2009b).

Problem gamblers believe erroneously in their ability to affect the likelihood of winning (Hoorens, 1994; Wohl \& Enzle 2003; Wohl et al., 2007). Belief in luck leads an individual to the illusion that his/her personal virtues would lead him/her in winning effects while financial losses are the result of external factors (lack of concentration, problematic roulette, etc) (Wohl \& Enzle 2003). 
Current neurobiological research has indicated that there is a dysregulation of dopaminergic system in pathological players. fMRI responses (Functional Magnetic Resonance Imaging) in dopaminergic system have shown that the peripheral dopamine's levels in the cerebrospinal fluid are abnormally regulated (Bergh et al., 1997; Meyer et al., 2004) during the performance of tasks relevant to gambling (Chase \& Clark, 2010; Reuter et al., 2005). Furthermore, dopamine agonists that are used in the treatment of Parkinson disease might produce disrupted gambling behavior as a side effect (Voon et al., 2009). Steeves et al., (2009) supported decreased activity in D2/D3 dopaminergic receptors in pathological gamblers. Increased impulsivity is indicated in substance dependent individuals that engage in pathological gambling as well (Verdejo-Garcia et al., 2008).

Dopamine is involved in learning, motives and reward's system. Alterations in dopaminergic system might lead an individual to seek for rewards (e.g. gambling) in order to stimulate dopamine secretion that provokes pleasurable emotions. Neuroimaging research have supported that minimized activity in ventral striatum, ventromedial prefrontal cortex and ventrolateral prefrontal cortex during pleasurable events might indicate a diminished neurophysiological response in reward and loss while the dopaminergic mesolimbic pathway from the ventral tegmental area to the nucleus accumbens seems to play a crucial role in gambling behavior (Reuter et al., 2005; De Ruiter et al., 2009). Contrary to what is expected due to dopamine's involution, antagonists of D2/D3 dopaminergic receptors increase motives and gambling behavior in patients with pathological gambling disorder (Zack \& Poulos, 2007) and do not have any effect in treatment (Fong et al., 2008; McElroy et al., 2008).

Problem gamblers indicated an increase in their motivation to gamble and positive statements towards gambling cue after amphetamine's administration in relation to control group (Zack \& Poulos, 2004; Zack \& Poulos, 2007). DRD1, DRD2, DRD3 genes of dopaminergic system seem to have some differentiations in pathological gamblers and substance abusers, supporting the hypothesis that there is a genetic basis of these disorders (Comings et al., 2001; Lobo et al., 2010; Lobo \& Kennedy, 2009). Genetic research on gambling disorder have supported some mutated polymorphisms in gene coding for dopamine receptor and in gene coding for monoamine oxidase A (Ibanez et al., 2003).

Norepinephrine (NE) has been implicated to mediate in aspects of attention, arousal and sensation seeking in pathological gamblers (Potenza \& Hollander, 2002). High concentration levels of norepinephrine and norepinephrine metabolites have been found in pathological versus non pathological players (Bullock \& Potenza, 2012). Norepinephrine levels increase when social players gamble (Shinohara et al., 1999; Meyer et al., 2004), while exceed in individuals with pathological gambling behavior (Meyer et al., 2004). Furthermore, there are high levels of cortisol during gambling 
not only in pathological but in non pathological players as well (Bullock \& Potenza, 2012).

Serotonergic neurotransmitter (5-HT) has been accused for deficient impulse control in pathological gamblers (DeCaria et al., 1998; Pallanti et al., 2006). Abnormalities in the concentration of 5-hydroxytryptamine $(5-\mathrm{HT})$ and its metabolites in the cerebrospinal fluid have been demonstrated in individuals with impulse control disorders (Nordin \& Eklundh, 1999; Nordin \& Sjodin, 2006). Literature research has shown contradictory outcomes. A research study conducted by Nordin \& Eklundh, (1999) indicated low levels of 5-hydroxyindoloacetic acid (5-HIAA) concentration in males with pathological gambling. On the other hand, high levels of 5hydroxyindoloacetic acid (5-HIAA) and low levels of tryptophan and serotonin (5-HT; 5 -hydroxytryptamine) in the cerebrospinal fluid have been referred in pathological gamblers (Nordin \& Sjodin, 2006). Decreased platelet levels in monoamine oxidase A (MAOA) and monoamine oxidase $B(M A O B)$ are present in pathological gamblers (DeCaria et al., 1998). The decreased levels in the cerebrospinal fluid of 5hydroxyindoloacetic acid (5-HIAA) have been related to other emotional states such as violence, suicidal behavior and aggressiveness (Cardinal, 2006) and other impulse control disorders (Blanco et al., 2000; DeCaria et al., 1996).

Evidence for serotonin dysfunction in pathological gamblers derives from pharmacological treatment where Selective Serotonin Reuptake Inhibitors (SSRIs) seem to be effective in decreasing symptoms of pathological gambling (Hollander et al., 1998; Hollander et al., 1992).

It becomes apparent to pathological gamblers a diminished response in prolactin after the administration of clomipramine (CMI), a tricyclic antidepressant that inhibits serotonin (5-HT) and norepinephrine (NE) reuptake (Moreno et al., 1991; DeCaria et al., 1998). Males with pathological gambling behavior indicated an increased prolactin response following the administration of $\mathrm{m}$-chlorophenylpiperazine $(\mathrm{m}$ -

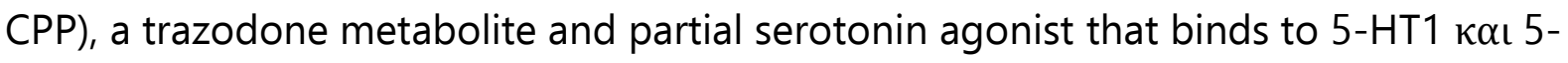
HT2 serotonergic receptors (Moreno et al., 1991). Pathological gamblers as compared to non pathological gamblers demonstrated a euphoric response and increased sensation seeking behaviors after the administration of $\mathrm{m}$ chlorophenylpiperazine (m-CPP) (DeCaria et al., 1998; Pallanti et al., 2006). Differential neuroendocrine responses to $m$-chlorophenylpiperazine ( $m$-CPP) have been related to the seriousness of pathological gambling (Pallanti et al., 2006) and have been reported in impulsive individuals or those diagnosed with other obsessive compulsive disorders (Potenza \& Hollander, 2002), indicating serotonin dysregulation (5-HT) not only in pathological gambling but in other impulse control disorders as well.

From a sociological perspective, pathological gambling is attributed to a person's deficiency to face society. Social structures (e.g. facilities and social relationships) in a gambling context, play a crucial role not only in development but in continuation of 
pathological gambling as well. Social reinforcements include social interaction, financial profits, personality exhibition, decision making (Ocean \& Smith, 1993).

Social reinforcements were more appealing for gamblers from low socioeconomic status and those who belonged in minority groups. Furthermore, stressful childhood situations such as neglect are related to more serious problems and lower age of onset of gambling behavior (Hodgins et al., 2010; Petry \& Steinberg, 2005). Early exposure in gambling may influence gambling behavior in older age (Oei \& Raylu, 2004; Schreiber et al., 2009).

Pathological Gambling contributes to dysfunctional family relationships, leads to high rates of separation and divorce, and is associated with spouse and child abuse and neglect (Shaw et al., 2007; Afifi et al., 2010). Family studies have shown that the risk of developing pathological gambling is higher than expected due to the combination of environmental and genetic factors (Walters, 2001). First degree relatives of pathological gamblers report high levels of alcohol and substance misuse, suffer from depressive and anxiety disorders and gamble excessively (Black et al., 2006).

In 2017 the Greek gambling market grew by 4\%. Official data, provided by the Hellenic Ministry of Finance, showed that betting outcome accounted for 11.3 billion EUR, compared to 10.8 billion in 2016. Therefore, every month the amount spent on gambling was about to 1 billion EUR (Hellenic Gaming Commission, 2018). This rise was mainly caused by online gambling. It is important to notice that the above data refer only to official rates and not to actual gambling rates, as the existence of illegal betting remains high and therefore there is an increase in gambling behavior in the Greek population.

Despite the increased availability of environmental contexts for gambling and the attention that gaming process has received from media, legal frameworks and industry, researchers have only recently begun to approach this disorder in a more comprehensive and scientific way. In Greece, research, prevention and treatment approach of pathological gamblers are in embryonic stage. Pathological gambling is thought to be untreatable due to the fact that very little research has been conducted in this area and on the other side, gamblers rarely seek treatment. On the other hand, responsible gambling is a form of recreational activity, where players make an informed choice of wagering and sustain their state of well-being. Therefore, this study has focused on Greek population in order not only to address the significance of the topic, but to inform either gamblers or/and their family members on the extent of their gambling behavior.

The main contributions of this paper are as follows:

1. Determine the prevalence of problem gambling among different sociodemographic groups in Greece 
2. Identify key factors that discriminate problem/pathological gamblers from the general population

3. Design, validate and administrate a self evaluation tool that would identify gambling disorder in Greek population.

The rest of this paper is organized as follows: In Section "Methodology", the methods and materials of this study are described, analyzing the three phases of the construction of the self evaluation tool. The "Results" Section refers to the following key results: A. Factor Analysis of final questionnaire, B. Reliability, C. Validity (1. Content, 2. Face, 3. Criterion, 4. Construct), D. Logistic Regression Analysis. Finally, a discussion on the main results and some concluding remarks are made.

\section{Methodology}

The design of the instrument was based on a variety of parameters that have been related to gambling behavior and procedure has been accomplished through various stages. As shown in Table 1, Table 2 and Table 3, there are not potential differences in the demographic characteristics of participants between the three different phases of methodology.

\section{Phase 1: Interview}

Pilot study consisted of a structured and semi-structured interview in 16 individuals that carried out face to face by the researchers during November 2011 - December 2011. The first stage in the development of this questionnaire was a qualitative phase. The sample contained a range of individuals covering a wide range of age, educational background and socioeconomic status. The demographic characteristics of the participants are shown in Table 1.

In addition, a comprehensive review of existing instruments for assessing problem gambling was undertaken. Participants were asked about general demographics and completed the following scales:

1. South Oaks Gambling Screen (SOGS; Lesieur \& Blume, 1987)

2. Victorian Gambling Screen (VGS; Ben-Tovim et al., 2001)

3. General open Questions that referred to gambling and gambling behavior

4. Inventory of Gambling Situations (IGS; Littman - Sharp et al., 2009)

5. Gambling Related Cognitions Scale (GRCS; Raylu \& Oei, 2004)

6. Eating Attitudes Test (EAT-26; Garner \& Garfinkel, 1979; Garner et al., 1982)

7. Eysenck Personality Questionnaire (E.P.Q; Interpretation and Validation in Greek: Dimitriou, 1986)

8. Beck Depression Inventory (BDI; Beck \& Beamesderfer, 1974; Tzemos, 1984) 
Participants in this phase completed the South Oaks Gambling Screen (SOGS; Lesieur \& Blume, 1987) and three main categories were derived: 1. Non problem Gamblers, 2. Potential Pathological Gamblers - Problem Gamblers, 3. Probable Pathological Gamblers.

Table 1: Demographic Characteristics of participants in Phase 1

\begin{tabular}{|c|c|c|}
\hline \multicolumn{3}{|c|}{ Demographic Characteristics } \\
\hline \multirow[t]{2}{*}{ Gender } & Male & $10(62,5 \%)$ \\
\hline & Female & $6(37,5 \%)$ \\
\hline \multirow[t]{5}{*}{ Age } & $20-30$ & $4(25,0 \%)$ \\
\hline & $31-40$ & $9(56,3 \%)$ \\
\hline & $41-50$ & $1(6,3 \%)$ \\
\hline & $51-60$ & $1(6,3 \%)$ \\
\hline & $61-70$ & $1(6,3 \%)$ \\
\hline \multirow[t]{4}{*}{ Marital Status } & Living with a partner & $4(25,0 \%)$ \\
\hline & Single & $3(18,8 \%)$ \\
\hline & Married & $8(50,0 \%)$ \\
\hline & Divorced/ Separated & $1(6,3 \%)$ \\
\hline \multirow[t]{4}{*}{ Educational Status } & Phd/Msc/ Ma Diploma & $5(31,3 \%)$ \\
\hline & University Diploma & $1(6,3 \%)$ \\
\hline & Technological Education Diploma & $7(43,8 \%)$ \\
\hline & High School Diploma & $3(18,8 \%)$ \\
\hline \multirow[t]{4}{*}{ Employment Status } & Full Time Employment & $13(81,3 \%)$ \\
\hline & Part Time Employment & $1(6,3 \%)$ \\
\hline & Homemaker & $1(6,3 \%)$ \\
\hline & Unemployed & $1(6,3 \%)$ \\
\hline \multirow[t]{4}{*}{ Occupational Status } & Federal Employee & $7(43,8 \%)$ \\
\hline & Private Employee & $6(37,5 \%)$ \\
\hline & Self - Employed & $1(6,3 \%)$ \\
\hline & Educator & $2(12,5 \%)$ \\
\hline \multirow[t]{8}{*}{ Annual Income } & 0-5.000 Euro & $1(6,3 \%)$ \\
\hline & $5001-10000$ Euro & $1(6,3 \%)$ \\
\hline & $10001-15000$ Euro & $2(12,5 \%)$ \\
\hline & $15001-20000$ Euro & $4(25,0 \%)$ \\
\hline & $20001-25000$ Euro & $5(31,3 \%)$ \\
\hline & $25001-30000$ Euro & $1(6,3 \%)$ \\
\hline & $30001-35000$ Euro & $1(6,3 \%)$ \\
\hline & Above 60001 & $1(6,3 \%)$ \\
\hline \multirow[t]{5}{*}{ Annual Family Income (if different) } & $10001-20000$ Euro & $2(25,0 \%)$ \\
\hline & $20001-30000$ Euro & $1(12,5 \%)$ \\
\hline & $30001-40000$ Euro & $1(12,5 \%)$ \\
\hline & $40001-50000$ Euro & $2(25,0 \%)$ \\
\hline & $60001-75000$ Euro & $2(25,0 \%)$ \\
\hline
\end{tabular}

The interview process included a range of semi-directed, open-ended questions and closed-ended questions referring to participants' perceptions of playing process, as 
well as to the way that social, psychological and biological factors involve in gambling. This pre-pilot version of the questionnaire contained different versions of many of the questions, enabling the designer to try out different wordings of the same concept. Furthermore, this interview contained a mixture of positive and negatively worded items, in order to prevent the development of a fixed response set.

After the completion of the interview, a variety of data reduction techniques (structural coding, determination of the number of factors that underlie the interrelationships, Factor extraction, Factor rotation) was used to remove redundant questionnaire items and questionnaire items with poor response properties. Qualitative analysis had been performed in open questions. Open questions were categorized and were entried in SPSS regarding either the actual responses received by the respondents or the previous research that have been conducted in the specific area. All remaining items were coded on a five-point Likert scale in order to rate the extent to which participants agree with each statement (where ' 1 ' is 'Totally disagree', ' 2 ' is Partially Disagree', ' 3 ' is 'Neither agree nor disagree', '4' is 'Partially Agree', and ' 5 ' is 'Totally agree'). Questions with poor response properties were those that:

1. Had same meaning in order for the experimenter to try different wording of the same item. Therefore, surplus questions have been removed as well as questions that were confusing for the subjects.

2. Appeared to have high number of missing values

3. Had factor loadings below a cut-off level of 0,3 (Comrey, 1973)

Furthermore, leading or biased, double - barreled, vague and negatively worded questions were removed from the pre - pilot version of the questionnaire.

Table 2: Demographic Characteristics of participants in Phase 2

\begin{tabular}{|c|c|c|}
\hline \multirow{2}{*}{ Gender } & Demographic Characteristics & \\
& Male & $43(46,7 \%)$ \\
\cline { 2 - 3 } & Female & $49(53,3 \%)$ \\
\hline \multirow{4}{*}{ Age } & $20-30$ & $70(76,1 \%)$ \\
\cline { 2 - 3 } & $31-40$ & $8(8,7 \%)$ \\
\cline { 2 - 3 } & $41-50$ & $8(8,7 \%)$ \\
\cline { 2 - 3 } & $51-60$ & $4(4,3 \%)$ \\
\cline { 2 - 3 } & $61-70$ & $2(2,2 \%)$ \\
\hline \multirow{4}{*}{ Marital Status } & Living with a partner & $48(52,2 \%)$ \\
\cline { 2 - 3 } & Single & $27(29,3 \%)$ \\
\cline { 2 - 3 } & Married & $16(17,4 \%)$ \\
\cline { 2 - 3 } & Divorced/ Separated & $3(1,1 \%)$ \\
\cline { 2 - 3 } & Phd/ Msc/ Ma Diploma & $7,6 \%)$ \\
\hline
\end{tabular}


Homo Virtualis 3 (1): 4-46, 2020, Charonitaki et al

\begin{tabular}{|c|c|c|}
\hline & Technological Education Diploma & $10(10,9 \%)$ \\
\hline & University Students & $47(51,1 \%)$ \\
\hline & High School Diploma & $23(25,0 \%)$ \\
\hline & Gymnasium Diploma & $2(2,2 \%)$ \\
\hline \multirow[t]{7}{*}{ Employment Status } & Full Time Employment & $20(21,7 \%)$ \\
\hline & Part Time Employment & $16(17,4 \%)$ \\
\hline & Homemaker & $1(1,1 \%)$ \\
\hline & Student & $44(47,8 \%)$ \\
\hline & Retired & $1(1,1 \%)$ \\
\hline & Unemployed & $9(9,8 \%)$ \\
\hline & Other (specify) & $1(1,1 \%)$ \\
\hline \multirow[t]{5}{*}{ Occupational Status } & Federal Employee & $5(8,6 \%)$ \\
\hline & Private Employee & $20(34,5 \%)$ \\
\hline & Self - Employed & $15(25,9 \%)$ \\
\hline & Educator & $3(5,2 \%)$ \\
\hline & Other (specify) & $15(25,9 \%)$ \\
\hline \multirow[t]{9}{*}{ Annual Income } & 0-5.000 Euro & $63(70,8 \%)$ \\
\hline & $5001-10000$ Euro & $6(6,7 \%)$ \\
\hline & $10001-15000$ Euro & $7(7,9 \%)$ \\
\hline & $15001-20000$ Euro & $1(1,1 \%)$ \\
\hline & $20001-25000$ Euro & $6(6,7 \%)$ \\
\hline & $30001-35000$ Euro & $2(2,2 \%)$ \\
\hline & $35.001-40.000$ Euro & $2(2,2 \%)$ \\
\hline & $45.001-50.000$ Euro & $1(1,1 \%)$ \\
\hline & $55.001-60.000$ Euro & $1(1,1 \%)$ \\
\hline \multirow[t]{10}{*}{ Annual Family Income (if different) } & $0-10.000$ Euro & $19(21,3 \%)$ \\
\hline & $10001-20000$ Euro & $13(14,6 \%)$ \\
\hline & $20001-30000$ Euro & $24(27,0 \%)$ \\
\hline & $30001-40000$ Euro & $16(18,0 \%)$ \\
\hline & $40001-50000$ Euro & $9(10,1 \%)$ \\
\hline & $50.001-60.000$ Euro & $4(4,5 \%)$ \\
\hline & $60001-75000$ Euro & $1(1,1 \%)$ \\
\hline & $75.001-100.000$ Euro & $1(1,1 \%)$ \\
\hline & $125.001-150.000$ Euro & $1(1,1 \%)$ \\
\hline & Above 150.000 Euro & $1(1,1 \%)$ \\
\hline \multirow[t]{3}{*}{ Player Subtype } & Non Problem Gambler & $61(67,0 \%)$ \\
\hline & Potential Pathological Gambler/ Problem Gambler & $9(9,9 \%)$ \\
\hline & Probable Pathological Gambler & $21(23,1 \%)$ \\
\hline
\end{tabular}

\section{Phase 2: Pilot version of the questionnaire}

Pilot version of the questionnaire was then developed, based on the results of the interview, an extensive review of the gambling literature and the authors' own clinical 
experience. The questionnaire contained a large bank of 227 questions: 176 questions referred to gambling and gambling behavior, 36 dealt with type and frequency of games of chance, while 15 collected personal details of respondents.

The sample of the pilot study consisted of 92 adults covering a wide range of age, educational background and socioeconomic status, as shown in Table 2. Participants in this phase were categorised in three main subtypes: 1. Non problem Gamblers, 2. Potential Pathological Gamblers - Problem Gamblers, 3. Probable Pathological Gamblers, according to the South Oaks Gambling Screen (SOGS; Lesieur \& Blume, 1987). Pilot study was carried out through December 2013 till October 2014. Respondents were approached in person by the researchers. Response rate at this phase was $46 \%$. This may be due to the time needed to answer all questions of the extensive form of this questionnaire.

Three main axes have been concluded in the pilot version of the questionnaire: $a$. Psychological (75 questions), b. Biological (52 questions), c. Sociological (49 questions). Principle axis factoring analysis with oblique rotation (oblimin) was performed in the three main axes of the questionnaire, considering eigenvalues higher than 1 (Kaiser's criterion) (Field, 2013). Furthermore, factor loadings over 0.3 were retained (Stevens, 1992). The Kaiser-Meyer-Olkin (KMO) measure was used to verify sampling adequacy of the analysis, with an acceptable limit for KMO values for individual items greater than 0.5 (Field, 2013). Psychological Axis KMO was $p=0.676$, Biological Axis KMO was $p=0.8$, Sociological Axis KMO was $p=0.784$. Questions that derived from the pilot questionnaire were: 39 items that referred to psychological axis, 27 items that referred to biological axis and 26 that referred to sociological axis. The questionnaire of next phase consisted of 148 items.

\section{Phase 3: Final questionnaire}

An extensive analytic process such as Exploratory Factor Analysis, Confirmatory Factor Analysis, Regression Analysis, was undertaken to arrive at the version of the questionnaire that would be tested in the final field study. Although that version was the final version, minor adjustments were still required as part of the validation process. Final adjustments of that type are part of the usual process of questionnaire development. One drawback of this study was that floor and ceiling effects were not assessed. Furthermore, there is a disproportionate number of items across factors. Adjustments should be made to reduce the size of the instrument while retaining the factor structure and its psychometric quality. Final questionnaire has been processed during November 2014 till May 2015.

The participants in the third phase were 200 adults; however, of these individuals, 20 decided not to participate for personal reasons and 9 were excluded due to missing data. Therefore, the final sample consisted of 171 Greek adults, 79 males and 92 females), aged from 20 to 70 years that have not been diagnosed with any other psychiatric disorder, covering a wide range of age, educational background and socioeconomic status as shown in Table 3. 
Table 3: Demographic Characteristics of participants in Phase 3

\begin{tabular}{|c|c|c|c|c|}
\hline \multicolumn{5}{|c|}{ Demographic Characteristics } \\
\hline & & $\begin{array}{c}\text { Non - problem } \\
\text { Gamblers (0-2 } \\
\text { criteria) }\end{array}$ & $\begin{array}{c}\text { Problem } \\
\text { Gamblers (3-4 } \\
\text { criteria) }\end{array}$ & $\begin{array}{c}\text { Probable } \\
\text { Pathological } \\
\text { Gamblers (5+ } \\
\text { criteria) }\end{array}$ \\
\hline \multirow[t]{2}{*}{ Gender } & Male & $29(17,0 \%)$ & $16(9,4 \%)$ & $34(19,9 \%)$ \\
\hline & Female & $59(34,5 \%)$ & $14(8,2 \%)$ & $19(11,1 \%)$ \\
\hline \multirow[t]{5}{*}{ Age } & $20-30$ & $60(35,1 \%)$ & $18(10,5 \%)$ & $27(15,8 \%)$ \\
\hline & $31-40$ & $17(9,9 \%)$ & $8(4,7 \%)$ & $11(6,4 \%)$ \\
\hline & $41-50$ & $9(5,3 \%)$ & $3(1,8 \%)$ & $9(5,3 \%)$ \\
\hline & $51-60$ & $2(1,2 \%)$ & $0(0,0 \%)$ & $4(2,3 \%)$ \\
\hline & $61-70$ & $0(0,0 \%)$ & $1(0,6 \%)$ & $2(1,2 \%)$ \\
\hline \multirow[t]{4}{*}{ Marital Status } & Living with a partner & $44(25,7 \%)$ & $9(5,3 \%)$ & $23(13,5 \%)$ \\
\hline & Single & $24(14,0 \%)$ & $12(7,0 \%)$ & $12(7,0 \%)$ \\
\hline & Married & $17(9,9 \%)$ & $9(5,3 \%)$ & $17(9,9 \%)$ \\
\hline & Divorced/ Separated & $3(1,8 \%)$ & $0(0,0 \%)$ & $1(0,6 \%)$ \\
\hline \multirow{6}{*}{$\begin{array}{l}\text { Educational } \\
\text { Status }\end{array}$} & Phd/Msc/ Ma Diploma & $8(4,7 \%)$ & $3(1,8 \%)$ & $8(4,7 \%)$ \\
\hline & University Diploma & $9(5,3 \%)$ & $5(2,9 \%)$ & $4(2,3 \%)$ \\
\hline & $\begin{array}{c}\text { Technological Education } \\
\text { Diploma }\end{array}$ & $15(8,8 \%)$ & $12(7,0 \%)$ & $13(7,6 \%)$ \\
\hline & University Students & $43(25,1 \%)$ & $6(3,5 \%)$ & $11(6,4 \%)$ \\
\hline & High School Diploma & $12(7,0 \%)$ & $4(2,3 \%)$ & $16(9,4 \%)$ \\
\hline & Gymnasium Diploma & $1(0,6 \%)$ & $0(0,0 \%)$ & $1(0,6 \%)$ \\
\hline \multirow{7}{*}{$\begin{array}{c}\text { Employment } \\
\text { Status }\end{array}$} & Full Time Employment & $16(9,4 \%)$ & $12(7,0 \%)$ & $27(15,8 \%)$ \\
\hline & Part Time Employment & $21(12,3 \%)$ & $7(4,1 \%)$ & $2(1,2 \%)$ \\
\hline & Homemaker & $3(1,8 \%)$ & $1(0,6 \%)$ & $0(0,0 \%)$ \\
\hline & Student & $41(24,0 \%)$ & $7(4,1 \%)$ & $12(7,0 \%)$ \\
\hline & Retired & $0(0,0 \%)$ & $0(0,0 \%)$ & $2(1,2 \%)$ \\
\hline & Unemployed & $7(4,1 \%)$ & $2(1,2 \%)$ & $10(5,8 \%)$ \\
\hline & Other (specify) & $0(0,0 \%)$ & $1(0,6 \%)$ & $0(0,0 \%)$ \\
\hline \multirow{5}{*}{$\begin{array}{c}\text { Occupational } \\
\text { Status }\end{array}$} & Federal Employee & $5(3,6 \%)$ & $5(3,6 \%)$ & $7(5,1 \%)$ \\
\hline & Private Employee & $23(16,8 \%)$ & $10(7,3 \%)$ & $17(12,4 \%)$ \\
\hline & Self-Employed & $15(10,9 \%)$ & $3(2,2 \%)$ & $16(11,7 \%)$ \\
\hline & Educator & $6(4,4 \%)$ & $1(0,7 \%)$ & $1(0,7 \%)$ \\
\hline & Other (specify) & $14(10,2 \%)$ & $8(5,8 \%)$ & $6(4,4 \%)$ \\
\hline \multirow[t]{12}{*}{ Annual Income } & 0-5.000 Euro & $55(32,7 \%)$ & $16(9,5 \%)$ & $22(13,1 \%)$ \\
\hline & $5001-10000$ Euro & $12(7,1 \%)$ & $6(3,6 \%)$ & $6(3,6 \%)$ \\
\hline & $10001-15000$ Euro & $9(5,4 \%)$ & $5(3,0 \%)$ & $8(4,8 \%)$ \\
\hline & $15001-20000$ Euro & $5(3,0 \%)$ & $1(0,6 \%)$ & $5(3,0 \%)$ \\
\hline & $20001-25000$ Euro & $1(0,6 \%)$ & $1(0,6 \%)$ & $6(3,6 \%)$ \\
\hline & $25000-30000$ Euro & $0(0,0 \%)$ & $0(0,0 \%)$ & $1(0,6 \%)$ \\
\hline & $30001-35000$ Euro & $2(1,2 \%)$ & $0(0,0 \%)$ & $0(0,0 \%)$ \\
\hline & $35.001-40.000$ Euro & $0(0,0 \%)$ & $0(0,0 \%)$ & $2(1,2 \%)$ \\
\hline & $45.001-50.000$ Euro & $1(0,6 \%)$ & $0(0,0 \%)$ & $1(0,6 \%)$ \\
\hline & $50000-55000$ Euro & $0(0,0 \%)$ & $0(0,0 \%)$ & $1(0,6 \%)$ \\
\hline & $55.001-60.000$ Euro & $0(0,0 \%)$ & $1(0,6 \%)$ & $0(0,0 \%)$ \\
\hline & Above 60000 Euro & $0(0,0 \%)$ & $0(0,0 \%)$ & $1(0,6 \%)$ \\
\hline Annual Family & $0-10.000$ Euro & $19(11,3 \%)$ & $7(4,2 \%)$ & $10(6,0 \%)$ \\
\hline
\end{tabular}




\begin{tabular}{|c|c|c|c|c|}
\hline $\begin{array}{c}\text { Income (if } \\
\text { different) }\end{array}$ & $10001-20000$ Euro & $19(11,3 \%)$ & $9(5,4 \%)$ & $13(7,7 \%)$ \\
\cline { 2 - 4 } & $20001-30000$ Euro & $22(13,1 \%)$ & $7(4,2 \%)$ & $14(8,3 \%)$ \\
\cline { 2 - 5 } & $30001-40000$ Euro & $11(6,5 \%)$ & $4(2,4 \%)$ & $6(3,6 \%)$ \\
\cline { 2 - 5 } & $40001-50000$ Euro & $7(4,2 \%)$ & $1(0,6 \%)$ & $7(4,2 \%)$ \\
\cline { 2 - 5 } & $50001-60000$ Euro & $4(2,4 \%)$ & $1(0,6 \%)$ & $1(0,6 \%)$ \\
\cline { 2 - 5 } & $60001-75000$ Euro & $1(0,6 \%)$ & $0(0,0 \%)$ & $0(0,0 \%)$ \\
\cline { 2 - 5 } & $75001-100000$ Euro & $1(0,6 \%)$ & $0(0,0 \%)$ & $1(0,6 \%)$ \\
\cline { 2 - 5 } & $125001-150000$ Euro & $0(0,0 \%)$ & $1(0,6 \%)$ & $0(0,0 \%)$ \\
\cline { 2 - 5 } & Above 150000 Euro & $1(0,6 \%)$ & $0(0,0 \%)$ & $1(0,6 \%)$ \\
\hline
\end{tabular}

Participants in this phase were categorised in three main subtypes: 1 . Non problem Gamblers, 2. Potential Pathological Gamblers - Problem Gamblers, 3. Probable Pathological Gamblers, according to DSM- IV diagnostic criteria as revised for the purposes of this study (Table 4).

In the second and third stage of this study, cluster sampling was conducted, based on the selection of certain functional groups, which constituted the sampling unit. The procedure followed for the implementation of the method was the random selection of whole groups involved in counselling and adult programs organized by the Youth Foundation and Lifelong Learning (INEDIVIM) in Heraklion - Crete. Also, some online questionnaires were administered to people who had visited a betting agency during last month. Data collection was performed either in person or via computer by the researchers. Response rate at this phase of the study was $85,5 \%$.

Table 4: Questionnaire Scoring Based on DSM - IV Diagnostic Criteria

\begin{tabular}{|c|c|}
\hline DSM - IV Diagnostic Criteria & $\begin{array}{l}\text { DSM- IV diagnostic criteria as revised for the } \\
\text { purposes of this study }\end{array}$ \\
\hline $\begin{array}{l}\text { 1. Preoccupation with gambling (e.g., } \\
\text { preoccupation with reliving past gambling } \\
\text { experiences, handicapping or planning the next } \\
\text { venture, or thinking of ways to get money with } \\
\text { which to gamble) }\end{array}$ & $\begin{array}{l}\text { 1. I keep gambling and relive past gambling } \\
\text { experiences due to the fact that I have win at the } \\
\text { past. }\end{array}$ \\
\hline $\begin{array}{l}\text { 2. A need to gamble with increasing amounts of } \\
\text { money in order to achieve the desired } \\
\text { excitement }\end{array}$ & $\begin{array}{l}\text { 1. I keep betting money on gambling when I feel } \\
\text { an urge to play } \\
\text { 2. I keep betting more money on gambling when I } \\
\text { feel that I am taking a risk. } \\
\text { 3. I keep betting more money on gambling when I } \\
\text { am seeking some kind of action. }\end{array}$ \\
\hline $\begin{array}{l}\text { 3. Repeated unsuccessful efforts to control, cut } \\
\text { back, or stop gambling }\end{array}$ & $\begin{array}{l}\text { 1. I have bet money on gambling when I believed } \\
\text { that I could play without exceeding the limits. } \\
\text { 2. I have gambled more than I intended to. }\end{array}$ \\
\hline $\begin{array}{l}\text { 4. Restlessness or irritability when attempting to } \\
\text { cut down or stop gambling }\end{array}$ & $\begin{array}{l}\text { 1. Every time I am gambling I feel relaxed. } \\
\text { 2. When I gamble, I feel that I am minimizing the } \\
\text { anger or distress that I am feeling. }\end{array}$ \\
\hline $\begin{array}{l}\text { 5. Use of gambling as a way to escape from } \\
\text { problems or relieve a dysphoric } \\
\text { mood (e.g., feelings of helplessness, guilt, }\end{array}$ & 1. I gamble in order to minimize the loneliness I am \\
\hline
\end{tabular}




\begin{tabular}{|c|c|}
\hline anxiety, depression) & $\begin{array}{l}\text { situations. } \\
\text { 3. Sometimes, I gamble when I feel I cannot stand } \\
\text { some situations and I need to get away. } \\
\text { 4. When I gamble, I feel that I minimize the anxiety } \\
\text { and stress that I am feeling. } \\
5 \text {. I bet money on gambling when there are fights at } \\
\text { home. }\end{array}$ \\
\hline $\begin{array}{l}\text { 6. After losing money gambling, one often } \\
\text { returns another day to get even } \\
\text { ("chasing" one's losses) }\end{array}$ & $\begin{array}{l}\text { 1. When I gamble, I go back another day to try to } \\
\text { win back the money I have lost } \\
\text { 2. I bet money on gambling when I need to win back } \\
\text { the money I have lost. }\end{array}$ \\
\hline $\begin{array}{l}\text { 7. Lying to family members, therapist, or others } \\
\text { to conceal the extent of } \\
\text { involvement with gambling }\end{array}$ & $\begin{array}{l}\text { 1. I have claimed that I earned money from gambling } \\
\text { when in fact I had lost. } \\
\text { 2. I have hidden betting slips, lottery tickets, } \\
\text { gambling money, or other signs of betting or } \\
\text { gambling from my family members }\end{array}$ \\
\hline $\begin{array}{l}\text { 8. Committing illegal acts, such as forgery, fraud, } \\
\text { theft, or embezzlement, to finance gambling }\end{array}$ & $\begin{array}{l}\text { 1. I have borrowed money to gamble or to pay } \\
\text { gambling debts, from credit cards. } \\
\text { 2. I have borrowed money to gamble or to pay } \\
\text { gambling debts, from my checking accounts (passed } \\
\text { bad checks). } \\
\text { 3. I have borrowed money and not paid him/her } \\
\text { back as a result of my gambling. }\end{array}$ \\
\hline $\begin{array}{l}\text { 9. Jeopardizing or losing a significant } \\
\text { relationship, job, or educational or career } \\
\text { opportunity because of gambling }\end{array}$ & $\begin{array}{l}\text { 1. Sometimes I have lost time from my work (or my } \\
\text { school) due to my gambling. } \\
\text { 2. My spouse/ partner does not seem to trust me } \\
\text { due to my gambling behavior. } \\
\text { 3. I felt getting away from my friends when I started } \\
\text { gambling more often. } \\
\text { 4. My gambling behavior has worsen my relationship } \\
\text { with my spouse/ partner. } \\
\text { 5. My gambling behavior has worsen my relationship } \\
\text { with my family. }\end{array}$ \\
\hline $\begin{array}{l}\text { 10. Relying on others to provide money to } \\
\text { relieve a desperate financial situation caused by } \\
\text { gambling. }\end{array}$ & $\begin{array}{l}\text { 1. I have borrowed money to gamble or to pay } \\
\text { gambling debts, from family members, friends or } \\
\text { from personal or family property. }\end{array}$ \\
\hline \multicolumn{2}{|c|}{$\begin{array}{l}\text { Scoring: Rate } 1 \text { grade if the participant's answers are either «Partially Agree» or «Totally Agree» in only } \\
\text { one of the items that refer to each specific criterion. Maximum score: } 10 \text { grades } \\
0-2 \text { criteria: Non problem gambler } \\
\text { 3-4 criteria: Potential Pathological Gambler - Problem Gambler } \\
\text { Above } 5 \text { criteria: Probable Pathological Gambler }\end{array}$} \\
\hline
\end{tabular}

Factor analysis with Oblique rotation was performed in order to reduce more the extent of the pilot questionnaire, that met the following criteria: (a) minimum factor eigenvalues of 1 ; (b) exclusion of items with factor loadings less than 0.3 based on Comrey' and Lee' (1992) suggestion that this cut-off point was appropriate for interpretative purpose; (c) Any items with double factor loadings were deleted. 
Therefore, 115 items were statistically significant and formed the final version of the questionnaire: 32 from the psychological axis, 19 from the biological axis, 24 from the sociological axis and the remaining 40 referred to the types of gambling, the ways of financing gambling and personal - demographic information.

\section{Results}

\section{A. Factor Analysis of final questionnaire}

The constructed psychometric instrument was based in risk and protection factors of gambling behavior that are depicted in the following Table 5 (Zhuravliova, 2010):

Table 5: Risk and Protection Factors for Gambling Behavior

\begin{tabular}{|c|c|}
\hline \multicolumn{2}{|c|}{ BIOLOGICAL FACTORS } \\
\hline Risk/ Danger & Protection \\
\hline $\begin{array}{l}\text { 1. There are genetic factors causing addictive } \\
\text { behavior. }\end{array}$ & $\begin{array}{l}\text { 1. There are not genetic factors causing } \\
\text { addictive behavior. }\end{array}$ \\
\hline 2. There is family history for addiction. & 2. There is not family history for addiction. \\
\hline $\begin{array}{l}\text { 3. There is an assumption for dopamine's } \\
\text { involvement (dopamine D2 receptor gene; } \\
\text { DRD2). }\end{array}$ & $\begin{array}{l}\text { 3. There is not an assumption for dopamine's } \\
\text { involvement (dopamine D2 receptor gene; } \\
\text { DRD2). }\end{array}$ \\
\hline $\begin{array}{l}\text { 4. Elevated levels of endorphin plasma, } \\
\text { increased arousal. }\end{array}$ & $\begin{array}{l}\text { 4. Normal levels of endorphin plasma, normal } \\
\text { levels of arousal. }\end{array}$ \\
\hline $\begin{array}{l}\text { 5. Existence of unilateral physiological } \\
\text { hypotension or hypertension. }\end{array}$ & $\begin{array}{l}\text { 5. Non - existence of unilateral physiological } \\
\text { hypotension or hypertension. }\end{array}$ \\
\hline $\begin{array}{l}\text { 6. Dysfunction of the serotonin system }(5-\mathrm{HT}) \text {. } \\
\text { 7. Less differential hemispheric activation. }\end{array}$ & $\begin{array}{l}\text { 6. Normal activity of the serotonin system (5- } \\
\text { HT). }\end{array}$ \\
\hline 8. Gender: Men gamble more money, often. & 7. Normal hemispheric differentiation. \\
\hline $\begin{array}{l}\text { They put higher bets and engage in more } \\
\text { risk-taking behavior. }\end{array}$ & $\begin{array}{l}\text { 8. Gender: Women gamble less money, rarely. } \\
\text { They do not put high bets and do not engage } \\
\text { in risk taking behavior. }\end{array}$ \\
\hline \multicolumn{2}{|c|}{ PSYCHOLOGICAL FACTORS } \\
\hline & \\
\hline \multicolumn{2}{|c|}{ Emotions } \\
\hline $\begin{array}{l}\text { 1. There is a psychological problem that } \\
\text { causes distress (e.g. repudiation, } \\
\text { uncertainty, divorce). }\end{array}$ & $\begin{array}{l}\text { 1. There is not a psychological problem that } \\
\text { causes distress (e.g. repudiation, uncertainty, } \\
\text { divorce). }\end{array}$ \\
\hline 2. Elevated depression levels. & 2. There are not elevated levels of depression. \\
\hline 3. Elevated anger levels & 3. There are not elevated levels of anger \\
\hline 4. There are high levels of anxiety. & 4. There are not high le \\
\hline 5. Individuals feel bored. & 5. Individuals do not feel bored \\
\hline $\begin{array}{l}\text { 6. Gambling behavior has a negative effect in } \\
\text { personal life. }\end{array}$ & $\begin{array}{l}\text { 6. Gambling behavior has not a negative effect } \\
\text { in personal life. }\end{array}$ \\
\hline \multicolumn{2}{|c|}{ Cognitive Elements } \\
\hline $\begin{array}{l}\text { 1. Searching of an altered/differentiated state } \\
\text { of consciousness. }\end{array}$ & $\begin{array}{l}\text { 1. Non - searching of an altered/differentiated } \\
\text { state of consciousness. }\end{array}$ \\
\hline 2. There are attention's deficit problems. & 2. There are not attention's deficit problems. \\
\hline
\end{tabular}


3. Suicidal ideation and/or suicidal attempts.

4. Cognitive distortions (illusion of control and erroneous beliefs).

5. The probability of winning tends to be overestimated whereas the probability of losing tends to be underestimated in a person's belief system.

6. The lucky game is a funding source.

7. An extreme, very positive attitude towards money.

8. Positive attitude towards lucky games and gambling.

9. Continuous thoughts about gambling.

10. They believe and make use of lucky charms.

11. They believe in certain gambling systems in order to win and they make use of them.
3. There are not suicidal ideation and/or suicidal attempts.

4. There are not cognitive distortions

5. The probabilities of winning or losing have a balance in a person's belief system.

6. The lucky game is not a funding source.

7. Non existence of an extreme, very positive attitude towards money.

8. Neutral and negative attitude towards lucky games and gambling.

9. There are not continuous thoughts about gambling.

10. They do not believe and do not make use of lucky charms.

11. They do not believe in certain gambling systems in order to win and they do not make use of them.

\section{Behavior}

1. Deficient control of impulsivity and search for feelings of excitement or intense emotions.

2. Low self - control and self - discipline

3. Low flexibility.

4. Poor coping skills.

5. They do not set time or money limits during gambling.

6. They do not seek for therapeutic interventions.

7. The amounts of money that are lost are important for the individual.

8. Lying to significant others towards gambling.

9. They spent much of their free time on gambling.

1. Potent control of impulsivity and non search for feelings of excitement or intense emotions.

2. High self - control and self - discipline

3. High flexibility.

4. Functional behavioral skills.

5. They do set time and money limits during gambling.

6. They do seek for therapeutic interventions.

7. The amounts of money that are lost are not important for the individual.

8. They do not lie to significant others towards gambling.

9. They do not spend their free time on gambling.

\section{Personality Traits}

1. Low Self-esteem.

2. Elevated competence.

3. Susceptible to various addictive behaviors (alcohol, substance abuse, eating disorder, etc).

\section{Psychopathology}

1. Increased measures in psychopathological 1 . There are not psychopathological deviances. deviances (MMPI).

2. Neurosis.

3. DSM-III antisocial personality criteria

4. Social Phobia.

5. Narcissistic personality disorder
1. High Self - esteem.

2. Normal Competence.

3. Non susceptible to other addictive behaviors.

SOCIAL FACTORS

Risk/ Danger

Family

Protection


1. Family members are not familiar with the side effects of gambling

2. Early onset of gambling behavior with family members.

3. Conflicts in conjugal relations

4. Remoted relations with extensive family members.

5. Familial traditional values regarding satisfactory family relations and obligations towards children are disputed.

\section{Relationships in social environment}

1. The social subgroup that the person belongs is involved in gambling behaviors (friends, Colleagues, relatives).

2. The type of occupation creates the opportunities for gambling.
1. Family members are familiar with the side effects of gambling

2. Family members do not engage in gambling behavior.

3. Functional conjugal relations.

4. Close relationships with extensive family members.

5. In accordance with familial traditional values.

\section{Social Settings}

1. Gambling is widely advertised and is available in young aged individuals.

2. The more the advertisements regarding gambling the more possible the increase of gambling attitudes.

3. Expanded availability of gambling and social acceptance.

4. The educators are not familiar with the exact percentage of children that gamble on an ordinal basis.

5. Gambling on work's place through internet.
1. The social subgroup that the person belongs does not involve in gambling behaviors (friends, Colleagues, relatives).

2. The type of occupation does not create opportunities for gambling.

1. Gambling is not widely advertised and is not available in young aged individuals.

2. The less the advertisements regarding gambling the less possible the increase of gambling attitudes.

3. Diminished availability of gambling and non social acceptance.

4. The educators are familiar with the exact percentage of children that gamble on an ordinal basis.

5. There is not access for gambling on work's place through internet.

\section{Culture}

1. Cultural conditions such as a dominant positive attitude towards gambling and values, traditions and positions of a society that supports gambling behavior.

1. Cultural conditions such as a dominant negative attitude towards gambling and values, traditions and positions of a society that does not support gambling behavior.

Source: Zhuravliova, I. (2010). Engaging in gambling as a psychosocial process in modern societies: the example of Greek society. (Phd Study), Athens: Panteion University, Department of Psychology.

Factor analysis was performed in the three broad axes that referred to psychological, biological and sociological criteria of gambling. For the purposes of the specific study, items that were selected should be loaded in one factor and had factor loadings more than 0.3 .

Regarding the psychological axis, Kaiser's-Meyer-Olkin measure which validates sampling adequacy was 0.929 , showing that the patterns of correlation are relatively compact, and thus, factor analysis should produce distinct and reliable factors (Field, 2000). Bartlett's Test of Sphericity was significant $(p=, 000)$ indicating that there were some relationships between the variables. Six factors were depicted from the 
psychological axis that accounted for $64,894 \%$ of variance in scores. The percentage of total variance of scores that is assumed valid is over $80 \%$ but in the majority of research studies this is quite difficult to be accomplished. Therefore, factors with eigenvalues greater than 1 are depicted according to Kaiser's criterion. The first axis contains 32 questions that refer to psychological parameters and comprises of six categories according to the factors that have been arisen from factor analysis: 1 . Cognitive Biases, e.g. I usually believe that after continuous losses in gambling, a series of wins follows, 2. Special Skills, e.g. I continue to gamble due to the fact that I have good memory recall system, 3. Way of thinking - Self - Control, e.g. I bet money on gambling when I believed that I could play without breaking my spending limit, 4. Lack of Interceptive Mechanisms - Lying e.g. I have claimed that I earned money from gambling when in fact I had lost, 5. Perceived Luck e.g. I believe that I will win if I hold with me my lucky charm, and 6. Behavior - Emotional State e.g. I use to gamble in order to escape from unpleasant situations.

Regarding the biological axis, Kaiser's-Meyer-Olkin measure was 0.937, and Bartlett's Test of Sphericity was found to be statistically significant $(p=, 000)$. Five factors were depicted from the biological axis that accounted for $64,879 \%$ of variance in scores. The five factors that derived from the model and consisted of 19 questions were: 1. Pleasure - Endogenous Opioids, e.g. Gambling entertains me 2. Physiological Responses, e.g. Sometimes, when I gamble, I feel hypertension, 3. Motives - Reward Seeking - Dopamine, e.g. Gambling has been a good hobby for me, 4. Anxiety Anger - Cortisol, e.g. I usually gamble when I want some action. 5. Instincts Biological Needs, e.g. Whenever I gamble, I usually forget to eat.

Biological axis is quite difficult to be evaluated in order to give reliable information on neurotransmitters that affect the causation or maintenance of this phenomenon. On the other hand, this axis could be used as a complementary scale of neuroimaging studies in which gamblers undergo in order to be tested whether specific biological factors contribute to the existence of pathological gambling.

Regarding the sociological axis, Kaiser's-Meyer-Olkin measure was satisfying $(, 892)$ and Bartlett's Test of Sphericity was found to be statistically significant $(p=, 000)$. Five factors were depicted from the sociological axis that accounted for $60,393 \%$ of variance in scores and consisted of 24 questions: 1. Social Group Attitudes - Family, e.g. Some people have criticized my gambling behavior regardless if I believed that was true, 2. Social Policy, e.g. Social services should preserve gambler's anonymity and handle him/her with discretion, 3. Couple and Family Relationships, e.g. My partner does not seem to trust me due to my gambling behavior, 4. Social Pressure, e.g. I use to gamble when someone encourages me to bet and 5. Inability to cope with stressful situations, e.g. I use to gamble when I worry about my debts.

Subscales referred in the three abovementioned parameters were modified from the Risk and Protection Factors for Gambling Behavior that derived from Zhuravliova (2010) study, as shown in Table 5. 


\section{B. Reliability}

Internal consistency of an instrument indicates whether items on a test (or a subscale of a composite test), that are intended to measure the same construct, produce consistent scores (Cortina, 1993). Cronbach's alpha is the most applied measure of internal consistency and was used in order to test the reliability of the specific questionnaire. Regarding all items Cronbach's alpha was $\alpha=0,973$, whereas for items of the three axes (biological, psychological and sociological) as well as for items referring to the ways of financing gambling Cronbach's alpha was $\alpha=0,977$, indicating high reliability in both cases. Pearson linear correlation was conducted with correlations ranging from -0.278 to +0.747 . Most statements are an indication that the internal consistency of the scale is high. Results of Cronbach's alpha are shown in Table 6 . Table 7 provides the inter-item correlation values of overall questionnaire and three main subscales separately. The ideal range of average inter-item correlation is 0.15 to 0.50 (Clark \& Watson, 1995).

Table 6: Internal Consistency of the questionnaire

\begin{tabular}{|c|c|}
\hline Cronbach's Alpha for the overall questionnaire $(\mathrm{N}=116)$ &, 973 \\
\hline $\begin{array}{c}\text { Cronbach's Alpha for the subscales (psychological, biological, sociological, gambling } \\
\text { financing) }(\mathrm{N}=81)\end{array}$ &, 977 \\
\hline Cronbach's Alpha for psychological subscale $(\mathrm{N}=32)$ &, 958 \\
\hline Cronbach's Alpha for biological subscale $(\mathrm{N}=20)$ &, 934 \\
\hline Cronbach's Alpha for sociological subscale $(\mathrm{N}=24)$ &, 914 \\
\hline
\end{tabular}

Table 7: Inter - Item Correlation Values of questionnaire and three subscales

\begin{tabular}{|c|c|c|c|c|c|c|c|}
\hline & Mean & Min. & Max. & Range & $\begin{array}{c}\text { Max. } / \\
\text { Min. }\end{array}$ & Variance & $\begin{array}{c}\text { N of } \\
\text { Items }\end{array}$ \\
\hline $\begin{array}{c}\text { Inter-Item Correlations for the } \\
\text { overall questionnaire (N=116) }\end{array}$ &, 217 &,- 765 & 1,000 & 1,765 & $-1,306$ &, 051 & 116 \\
\hline $\begin{array}{c}\text { Inter-Item Correlations for psychological } \\
\text { subscale }\end{array}$ &, 415 &, 094 &, 716 &, 622 & 7,586 &, 011 & 32 \\
\hline $\begin{array}{c}\text { Inter-Item Correlations for biological } \\
\text { subscale }\end{array}$ &, 278 &, 049 &, 580 &, 531 & 11,894 &, 013 & 19 \\
\hline $\begin{array}{c}\text { Inter-Item Correlations for sociological } \\
\text { subscale }\end{array}$ &, 317 &,- 077 &, 779 &, 857 & $-10,090$ &, 027 & 24 \\
\hline
\end{tabular}

\section{Validity}

The following four types of validity were used in order for the questionnaire to be tested:

\section{Content Validity}

Content validity focuses on the coverage of the selected subject within the context of the wider issue under study and elements chosen for the research sample are 
processed in depth and breadth (Cohen et al., 2008). Therefore, this measure refers to the degree that items of a new questionnaire apply to the potential content to which the instrument will be generalized (Straub et al., 2004). Content validity takes into account the literature review as well as the experts' judges. Therefore, content validity was conducted in this study in order to check the operationalization against the relevant content domain for the construct. Firstly, the concept of problematic involvement with gambling was defined and the dimensions composing the variable to be measured were recorded in order to be included in the items of the constructed questionnaire. Therefore, questions that were ambiguous and created confusion to the interviewee were either corrected or rejected by the interviewer and three more people who had specialized knowledge in the target construct. Thus, in order to verify the content validity, a pilot study in 16 randomly selected subjects was carried out. Data associated with pathological gambling was recorded. The selection of items was based on thematic or conceptual relationship between observable behavior and the construct measured as well as on empirical data from previous studies that substantiated this specific relationship. Finally, once the items for the final version of the test had been selected, they were compared to the original description of the construct to ensure that all aspects of the construct remained equally well represented. Therefore, the items that had been selected seemed to have greater relevance to the object under study. This procedure was based on the subjective judgment of researchers. Questions were formulated in order to avoid inappropriate formalities leading to uncertainties and general confusion of the person completing the questionnaire.

\section{Face Validity}

Face validity is a subjective measure where participants or others that do not have any relevance with the subject under study, evaluate the questionnaires in terms of relevance, reasonability, unambiguity and clearness (Oluwatayo, 2012). In order to test face validity, professionals and respondents that were asked to evaluate the questionnaire regarded the items of this specific instrument as quite appropriate for the construct being assessed.

\section{Criterion Validity}

A criterion validity study was also conducted, which was based on another measurement instrument (SOGS), in order for researchers to evaluate whether the present instrument measures the construct being assessed. There are two types of criterion validity: concurrent validity and predictive validity. Concurrent validity refers to the extent to which a new assessment instrument is capable of predicting criteria that have been measured at the same point in time by another instrument that has indicated good psychometric properties (Saris \& Gallhofer, 2007). Predictive validity refers to the ability of a research tool to predict performance in future. In this research study, a concurrent validity of the questionnaire was conducted, using Spearman's non parametric test and was found $\rho=0,852$, sig $=0,000$ (Table 8 ), 
indicating that DSM-IV diagnostic criteria as revised for the purposes of this study in order to evaluate the gambler's pathology (Table 4) correlated significantly with SOGS. Consequently, individuals that demonstrated a high score in DSM-IV criteria for pathological gambling behavior, they have achieved higher scores in SOGS as well.

\section{Construct validity}

Construct validity of a measurement refers to the degree that the operational definition of a variable actually reflects the theoretical construct that was intended to be measured (Hajjar, 2018). In order to verify the construct validity (discriminant and convergent validity) of the assessment tool, three factor analyses were conducted. Firstly, in order to investigate the correlation between assessment instrument and literature context, factor analysis was undertaken on the three main axes of the pilot data. Then, factor analysis was conducted on the three main axes (psychological, biological, sociological) of the final questionnaire. Finally, Confirmatory Factor Analysis was applied, using IBM SPSS AMOS 20, in the three main axes of the questionnaire due to the fact that experimenters supported that measurements fits in an already familiar underlying structure, showing good fit for the data.

Table 8: Concurrent validity

\begin{tabular}{|c|c|c|c|c|}
\hline \multicolumn{5}{|c|}{ Correlations } \\
\hline & & & $\begin{array}{l}\text { DSM }- \text { IV } \\
\text { TOTAL SCORE }\end{array}$ & $\begin{array}{l}\text { SOGS TOTAL } \\
\text { SCORE }\end{array}$ \\
\hline \multirow[t]{6}{*}{$\begin{array}{l}\text { Kendall's tau correlation } \\
\text { coefficient }\end{array}$} & \multirow[t]{3}{*}{$\begin{array}{l}\text { DSM - IV } \\
\text { Total Score }\end{array}$} & $\begin{array}{l}\text { Correlation } \\
\text { Coefficient }\end{array}$ &, $730^{\star \star}$ & 1,000 \\
\hline & & $\begin{array}{l}\text { Significance level } \\
\text { (2-tailed) }\end{array}$ & ,000 & . \\
\hline & & $\mathrm{N}$ & 171 & 171 \\
\hline & \multirow[t]{3}{*}{$\begin{array}{ll}\text { SOGS Total } \\
\text { Score }\end{array}$} & $\begin{array}{l}\text { Correlation } \\
\text { Coefficient }\end{array}$ & 1,000 &, $730^{* \star}$ \\
\hline & & $\begin{array}{l}\text { Significance level } \\
\text { (2-tailed) }\end{array}$ & . &, 000 \\
\hline & & $\mathrm{N}$ & 171 & 171 \\
\hline \multirow[t]{6}{*}{ Spearman's rho } & \multirow[t]{3}{*}{$\begin{array}{l}\text { DSM - IV } \\
\text { Total Score }\end{array}$} & $\begin{array}{l}\text { Correlation } \\
\text { Coefficient }\end{array}$ & $852^{* *}$ & 1,000 \\
\hline & & $\begin{array}{l}\text { Significance level } \\
\text { (2-tailed) }\end{array}$ & ,000 & . \\
\hline & & $\mathrm{N}$ & 171 & 171 \\
\hline & \multirow[t]{3}{*}{$\begin{array}{ll}\text { SOGS } & \text { Total } \\
\text { Score } & \end{array}$} & $\begin{array}{l}\text { Correlation } \\
\text { Coefficient }\end{array}$ & 1,000 & $852^{* \star}$ \\
\hline & & $\begin{array}{l}\text { Significance level } \\
\text { (2-tailed) }\end{array}$ & . & ,000 \\
\hline & & $\mathrm{N}$ & 171 & 171 \\
\hline
\end{tabular}

Confirmatory Factor Analysis is used in cases where there is a priory specified relationship between items and latent variables and aims to determine whether data 
from a specific population confirms the specific model (Russell, 2002). If CFA provides a good fit to the data, it is assumed that earlier findings have a more general validity regardless the idiosyncrasies of pilot study sample.

The objective of confirmatory factor analysis was to convert the questionnaire items into a smaller number of unmeasured (latent) variables known as factors. Final adjustments to the content of questionnaire are often made at this stage. Some questions may add little or nothing to the questionnaire and will be removed.

Table 9: Model Fit Indices

\begin{tabular}{|c|c|}
\hline Model Fit Indices & Acceptable Limits \\
\hline $\begin{array}{l}\text { Chi-square/df } \\
(\mathrm{cmin} / \mathrm{df})\end{array}$ & $<3$ good, $<5$ sometimes permissible \\
\hline$P$-value & $>.05$ \\
\hline CFI & $\begin{array}{l}>.95 \text { good, }>.90 \text { moderate, }>.80 \text { sometimes permissible (Hu \& Bentler, } \\
\text { 1999) }\end{array}$ \\
\hline GFI & $>.95$ \\
\hline PCFI & $>.08$ \\
\hline SRMR & $<.09$ \\
\hline RMSEA & $\begin{array}{l}<.05 \text { good, } .05-.10 \text { moderate, >.10 bad (Hu \& Bentler, 1999; Byrne, } \\
\text { 2000) }\end{array}$ \\
\hline PCLOSE & $>.05$ \\
\hline
\end{tabular}

In order to test whether the proposed models show good fit to the data, four different goodness of fit indices should at least be used (Griffin, 2005). The goodness of fit indices that were examined in this study were: 1 . Chi-square/df $\left(x^{2} / d f\right), 2$. Goodness - of - Fit Index (GFI), 3. Comparative Fit Index (CFI: Bentler, 1990), 4. Parsimonious Comparative Fit Index (PCFI) 5. Root Mean Square Error of Approximation (RMSEA: Steiger, 1990), and 6. p of close fit (PCLOSE)

Null hypothesis means that the presumed covariance matrix is equivalent to the observed sample covariance matrix and $x^{2}$ evaluates the difference between the two of them. A large $x^{2}$ and rejection of null hypothesis, implicates that the model does not fit the data well. On the other hand a small $x^{2}$, below 2,0, and failure for the null hypothesis to be rejected, supports a good model fit. $x^{2}$ is quite sensitive in small sample and null hypothesis is extremely difficult to be retained when the sample's size increases (Jöreskog, 1969). Therefore, the alternative model fit indices that were used in this study are presented in Table 9 as well as their acceptable limits.

The fit statistics in psychological axis ranged from poor to fair as determined by criteria for model fit adequacy (Browne \& Cudeck, 1992; Hu \& Bentler, 1999). Contrary to hypotheses, this model did not provide a good overall fit to the data. Consequently, factor loadings for this model were evaluated to determine whether certain items did not load strongly on their hypothesized latent factor and whether the deletion of such items would enhance the fit of the model to the data. Therefore 15 items were deleted and a second confirmatory factor analysis in psychological axis 
was conducted that supported a five factor model. This revised model provided an adequate fit to the data (Browne \& Cudeck, 1992; Hu \& Bentler, 1999) because all fit statistics were acceptable as presented in Table 10 and Figure 1. CMIN value of 1,712 was satisfactory but $p$ value was still .000, (the null hypothesis was rejected) and this may be attributed to the abovementioned reasons. GFI (901), CFI (,924) and PCFI $(716)$ have improved significantly showing that the model fits well to the data. Finally, PCLOSE value of ,081 is acceptable while RMSEA value of 0,065 is good but it would be perfect if it was under 05 .

Table 10: Model Fit Indices for Psychological Axis

\begin{tabular}{|l|l|l|l|l|l|l|}
\hline Model & CMIN/DF & GFI & CFI & PCFI & RMSEA & PCLOSE \\
\hline $\begin{array}{l}\text { Default } \\
\text { model }\end{array}$ & 1,712 &, 901 &, 924 &, 716 &, 065 &, 081 \\
\hline
\end{tabular}

Figure 1: CFA for Psychological Axis

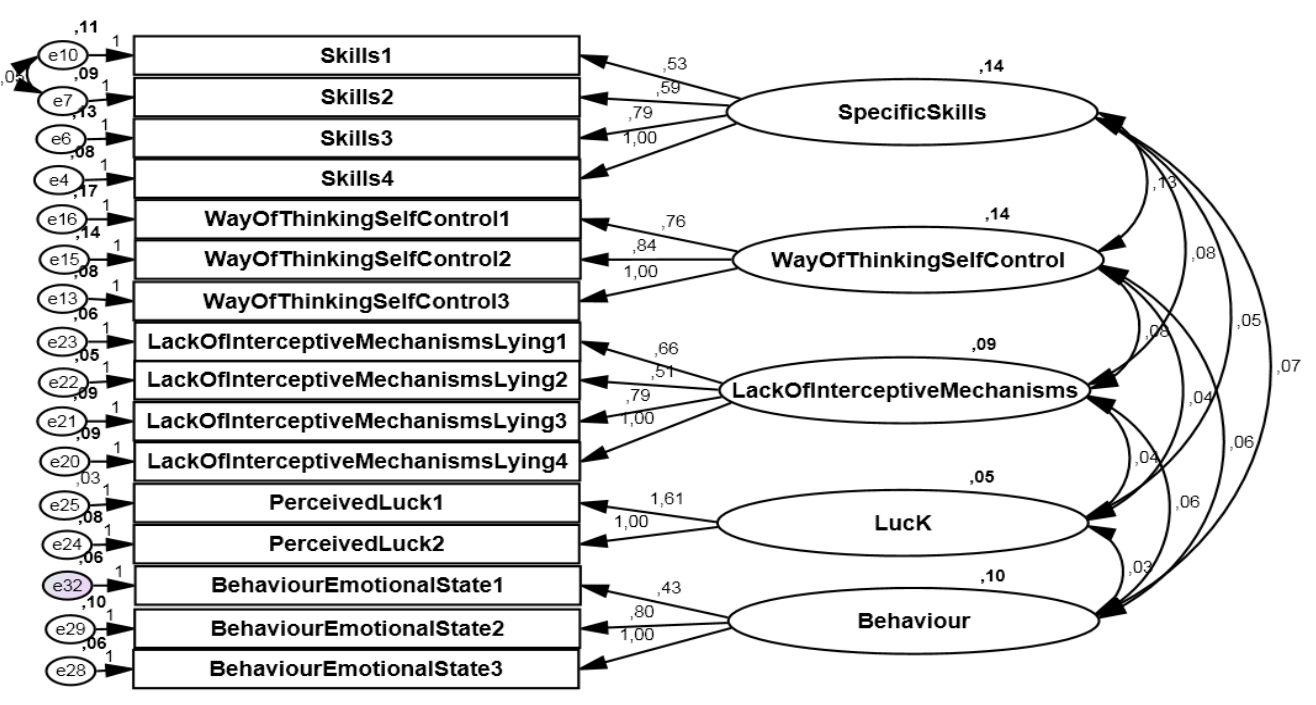

CFA was conducted in biological axis on four factors: 1. Pleasure - Endogenous Opioids, 2. Physiological Responses, 3. Motives - Reward Seeking - Dopamine, 4. Anger - Anxiety - Cortisol. The fifth factor of biological axis "Instincts - Biological Needs" was excluded from CFA though it was consisted of a single question. The fit statistics in biological axis were moderate as determined by criteria for model fit adequacy (Browne \& Cudeck, 1992; Hu \& Bentler, 1999). Therefore, some parameters were modified in order to improve model fit. 2 items were deleted and a second confirmatory factor analysis was conducted that supported a four factor model. This revised model provided an adequate fit to the data (Browne \& Cudeck, 1992; Hu \& Bentler, 1999) because all fit statistics were acceptable as presented in Table 11 and Figure 2. CMIN value of 1,441 was satisfactory but $p$ value was still .003, showing inadequate fit. GFI $(911)$ and CFI $(944)$ show perfect fit while PCFI $(, 771)$ is good but it could be perfect if it was more than the accepted limit of 0,8 . Finally, PCLOSE value 
of 0,450 is acceptable and RMSEA value of 0,051 is perfect though it is quite close to the accepted limit of .05 .

Table 11: Model Fit Indices for Biological Axis

\begin{tabular}{|c|c|c|c|c|c|c|}
\hline Model & CMIN/DF & GFI & CFI & PCFI & RMSEA & PCLOSE \\
\hline $\begin{array}{c}\text { Default } \\
\text { model }\end{array}$ & 1,441 &, 911 &, 944 &, 771 &, 051 &, 450 \\
\hline
\end{tabular}

Figure 2: CFA for Biological Axis

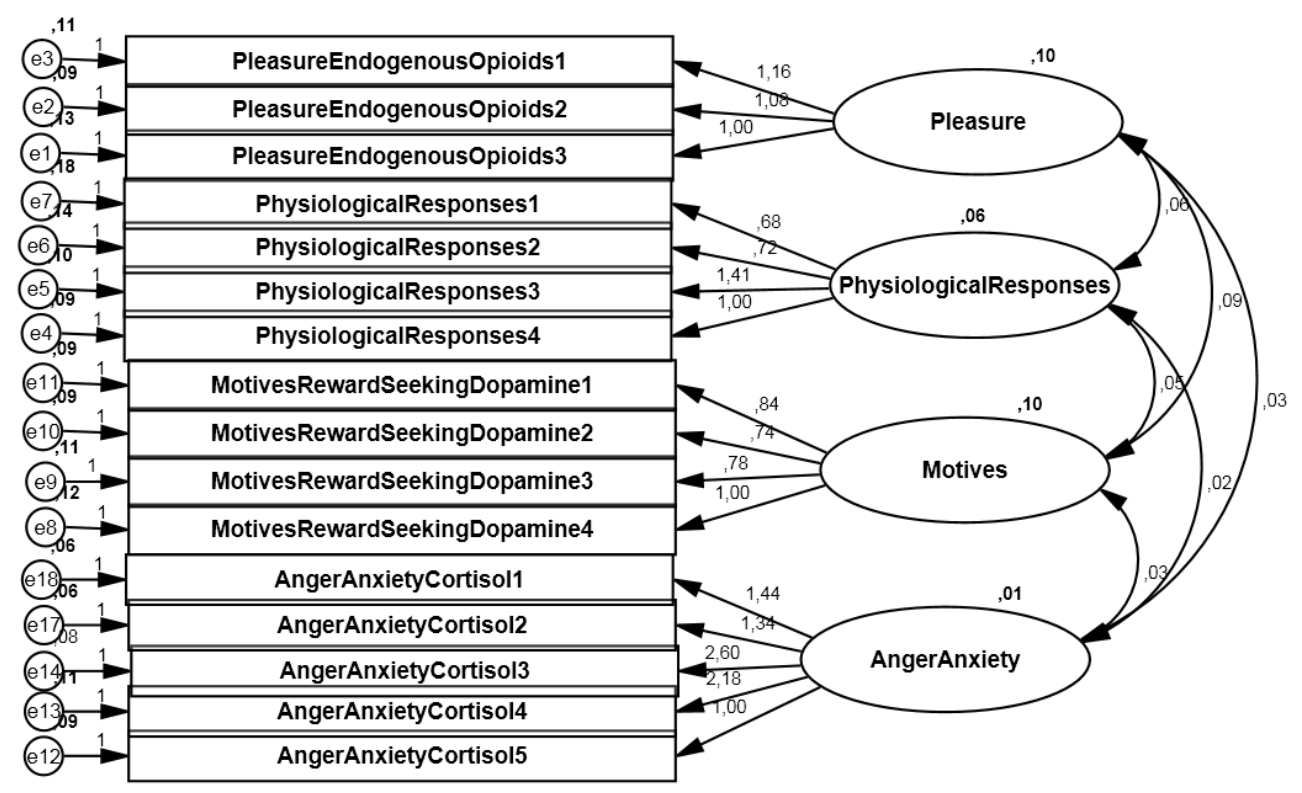

Table 12: Model Fit Indices for Sociological Axis

\begin{tabular}{|c|c|c|c|c|c|c|}
\hline Model & CMIN/DF & GFI & CFI & PCFI & RMSEA & PCLOSE \\
\hline Default model & 1,599 &, 868 &, 887 &, 756 &, 059 &, 115 \\
\hline
\end{tabular}

CFA was finally conducted in sociological axis on five factors: 1. Social Group Attitudes - Family, 2. Social Policy, 3. Couple and Family Relationships, 4. Social Pressure, and 5. Inability to cope with stressful situations. The fit statistics in sociological axis were moderate and modification index suggested that if 2 items were deleted the model would fit the data well. A second confirmatory factor analysis was conducted that supported a five factor model which provided an adequate fit to the data (Browne \& Cudeck, 1992; Hu \& Bentler, 1999) as presented in Table 12 and Figure 3. CMIN value of 1,599 is satisfactory but $p$ value is still .000 , showing 
inadequate fit. GFI $(, 868)$, CFI $(, 887)$ and PCFI $(756)$ are moderate but not perfect. Finally, PCLOSE value of 0,115 is acceptable and RMSEA value of 0,059 is quite satisfactory but not perfect.

Figure 3: CFA for Sociological Axis

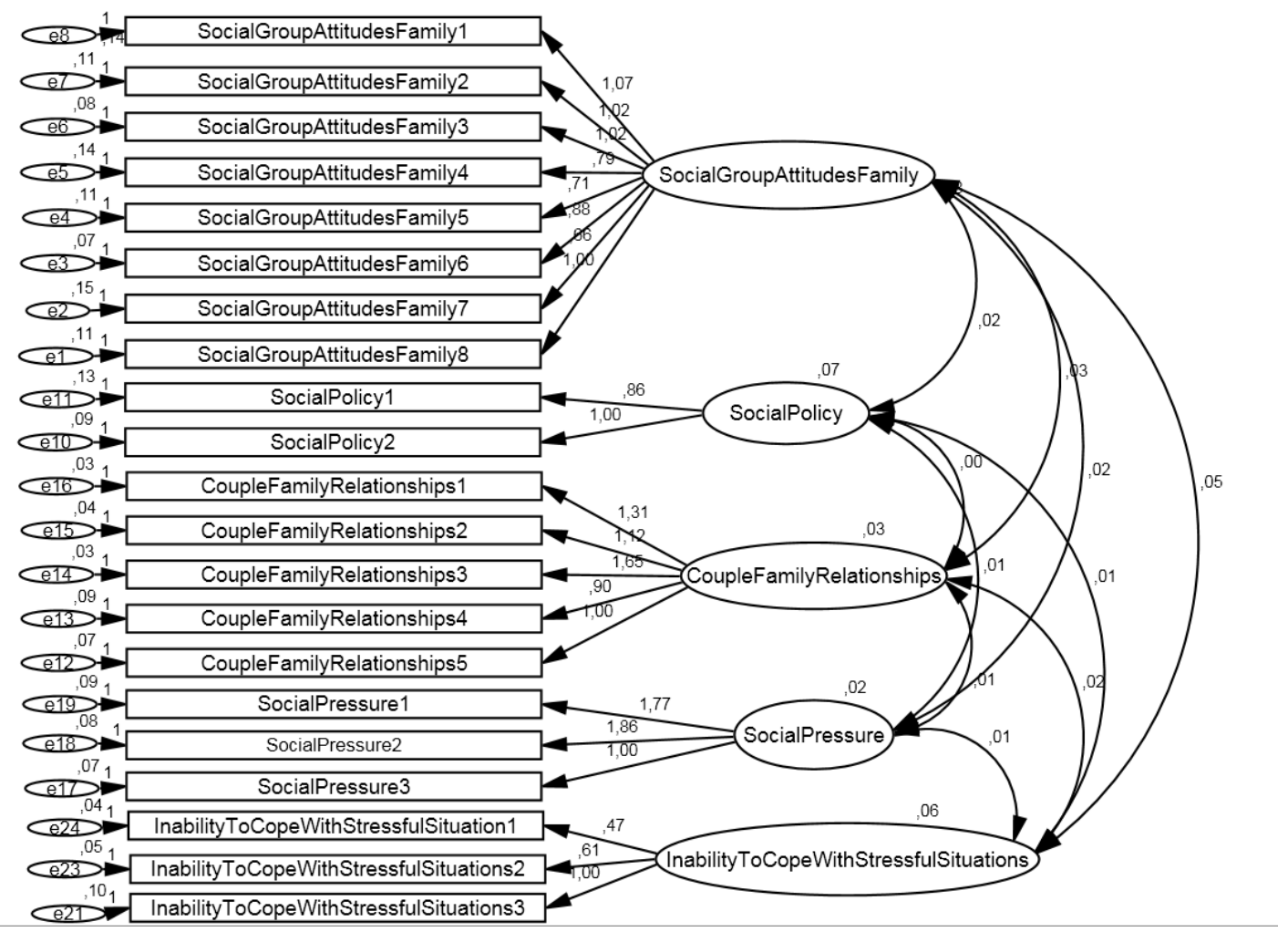

\section{Binary Logistic Regression Analysis}

A logistic regression analysis was performed in order for researchers to determine how much the variability of each independent variable contributes to the disposition of the dependent variable (Armitage \& Berry 1994). Logistic regression analysis was used to predict pathological gambling behavior (dichotomous variable: non problem gamblers/ problem or pathological gamblers), investigating which questions differentiate problem/ pathological gamblers from non gamblers. The motivation for that analysis was the observation that early diagnosis of pathological gambling is crucial for successful treatment (Achab et al., 2014). According the Wald criterion, 16 questions reliably predicted problem gambling. Table 13 shows regression coefficients.

\section{Discussion}

The present study focused on developing and validating a questionnaire that can screen for a range of gambling behavior as well as discriminate non problem from problem gamblers in a community sample.

In the present study is confirmed that the coexistence of biological, sociological and psychological factors leads to increased levels of pathological gambling. Results have 
shown that the existence of social factors that could determine pathological gambling becomes more evident since psychological factors $(77,8 \%, p<0,01)$ or/and biological factors $(70,8 \%, p<0,01)$ coexist. Furthermore, since psychological factors come along, that could lead players in gambling, the existence of biological factors $(69,0 \%, p<0,01)$ may be more apparent.

Table 13: Results of the logistic regression analysis of Gambling Category against three main axes of the questionnaire (psychological, biological, sociological)

\begin{tabular}{|c|c|c|c|c|c|c|}
\hline Questions & B & S.E. & Wald & $\mathrm{df}$ & Sig. & $\operatorname{Exp}(B)$ \\
\hline $\begin{array}{l}\text { After continuous losses in gambling, I usually consider } \\
\text { following a series of wins. (Psychological Axis) }\end{array}$ & $-3,664$ & 1,829 & 4,012 & 1 &, $045^{*}$ & 026 \\
\hline $\begin{array}{l}\text { I have bet money on gambling when I believed that I } \\
\text { could play without exceeding the limits. } \\
\text { (Psychological Axis) }\end{array}$ & $-2,528$ & 1,086 & 5,413 & 1 &, $020^{*}$ &, 080 \\
\hline $\begin{array}{l}\text { I keep betting money on gambling when I feel an } \\
\text { urge to play (Psychological Axis) }\end{array}$ & $-2,891$ & 1,404 & 4,242 & 1 &, $039^{*}$ & ,056 \\
\hline $\begin{array}{l}\text { Whenever I gamble, I have in mind a specific system } \\
\text { that can win the probabilities. (Psychological Axis) }\end{array}$ & $-3,396$ & 1,362 & 6,219 & 1 &, $013^{*}$ & ,033 \\
\hline $\begin{array}{l}\text { I have claimed that I earned money from gambling } \\
\text { when in fact I had lost. (Psychological Axis) }\end{array}$ & $-4,872$ & 1,421 & 4,051 & 1 &, $044^{*}$ & ,008 \\
\hline $\begin{array}{l}\text { I bet money on gambling when I need to win back } \\
\text { the money I have lost. (Psychological Axis) }\end{array}$ & $-4,330$ & 1,588 & 7,433 & 1 &, $006^{* *}$ & 013 \\
\hline Gambling excites me (Biological Axis) & $-1,418$ & ,687 & 4,261 & 1 & ,039* & ,242 \\
\hline $\begin{array}{l}\text { Every time I am gambling, I feel relaxed. (Biological } \\
\text { Axis) }\end{array}$ & $-4,116$ & 1,332 & 9,553 & 1 &, $002^{* *}$ & ,016 \\
\hline $\begin{array}{l}\text { I keep betting more money on gambling when I am } \\
\text { seeking some kind of action (Biological Axis) }\end{array}$ & $-4,664$ & 1,570 & 8,825 & 1 &, $003^{* *}$ & ,009 \\
\hline $\begin{array}{l}\text { Whenever I gamble, I usually forget to eat. (Biological } \\
\text { Axis) }\end{array}$ & $-3,585$ & 1,496 & 5,741 & 1 &, $017^{\star}$ & ,028 \\
\hline $\begin{array}{l}\text { Sometimes, I use to gamble when I feel lonely. } \\
\text { (Sociological Axis) }\end{array}$ & $-2,068$ & ,908 & 5,184 & 1 &, $023^{*}$ & ,126 \\
\hline $\begin{array}{l}\text { I use to gamble when I have free time and do not } \\
\text { know how else to make good use of it. (Sociological } \\
\text { Axis) }\end{array}$ & $-2,927$ & 1,067 & 7,521 & 1 &, $006^{* *}$ & ,054 \\
\hline $\begin{array}{l}\text { Sometimes, I have lost time from my work (or my } \\
\text { school) due to my gambling. (Sociological Axis) }\end{array}$ & $-2,738$ & ,839 & 10,640 & 1 &, $001^{\text {** }}$ & ,065 \\
\hline $\begin{array}{l}\text { My spouse/ partner does not seem to trust me due to } \\
\text { my gambling behavior. (Sociological Axis) }\end{array}$ & $-2,262$ & ,990 & 5,221 & 1 &, $022^{*}$ & , 104 \\
\hline $\begin{array}{l}\text { I use to gamble when someone encourages me to } \\
\text { bet. (Sociological Axis) }\end{array}$ & $-2,204$ & 1,027 & 4,607 & 1 &, $032^{\star}$ & 110 \\
\hline $\begin{array}{l}\text { I use to gamble when I worry about my debts. } \\
\text { (Sociological Axis) }\end{array}$ & $-3,047$ & 1,035 & 8,668 & 1 &, $003^{* *}$ & ,048 \\
\hline
\end{tabular}

${ }^{\star} \mathrm{p}<.05 ;{ }^{* *} \mathrm{p}<.01$ 
On further examination of the abovementioned three factors, it was conducted binary logistic regression in order to be emerged those questions that could predict problem and pathological gambling. Findings are consistent with biopsychosociological model (Sharpe \& Tarrier, 1993; Sharpe, 2002) and the model of Blaszczynski and Nower (2002). These models insist that some preceding factors (e.g. diminished ability in problem solving, genetic predisposition) interact with individual's early experiences on gambling (e.g. a significant win or many small wins) and adverse psychological experiences (e.g. boredom, stressful life events) that contribute in the development of disordered gambling.

Regarding regression analysis some interesting results have been found. Firstly, perceived luck or chasing (i.e. "After continuous losses in gambling, I usually consider following a series of wins", "Whenever I gamble, I have in mind a specific system that can win the probabilities", "I bet money on gambling when I need to win back the money I have lost.") seem to predict gamblers pathology. This is consistent with other studies claiming that cognitive distortions may lead to the development or maintenance of gambling disorder (Ladouceur, 2004). Problem/Pathological gamblers advocate more cognitive distortions than non-problem or social gamblers (Toneatto, 1999; Joukhador et al., 2004; Myrseth et al., 2010). Another variable that predicts gambling disorder is the weakness of set limit (i.e "I have bet money on gambling when I believed that I could play without exceeding the limits."). Most researches assert that problem/ pathological gamblers demonstrate more selfcontrol deficits and less emotional and cognitive self-control compared to non gamblers (Bergen et al., 2012). Regression analysis supported that gamblers use detachment as a way to rest and make them focus on a leisure activity in order to cope with everyday problems or stressful situations (i.e. "Every time I am gambling, I feel relaxed", "Sometimes, I use to gamble when I feel lonely", "I use to gamble when I have free time and do not know how else to make good use of it"). These results are consistent with previous research, supporting that detachment or escape is an important reason for gambling (Blaszczynski \& Nower, 2002; Sundqvist et al., 2016 ). Moreover, excitement, suspense and risk taking are considered quite common motivations for a gambler to engage in a gambling activity (Ely et al., 2015; Hahn et al., 2013). This became apparent in the present study, showing that problem/ pathological gamblers are more prone to gamble when they look for excitement, action or have an irresistible urge to play (i.e. "I keep betting money on gambling when I feel an urge to play", "Gambling excites me", "I keep betting more money on gambling when I am seeking some kind of action."). Another factor that emerged from regression analysis is social pressure (i.e. "I use to gamble when someone encourages me to bet"). Social motives seem to be a precipitating factor for gambling participation (Lambe et al., 2015; Lee et al., 2007). Trust - breaking behavior (i.e. "My spouse/ partner does not seem to trust me due to my gambling behavior") and lying (i.e. "I have claimed that I earned money from gambling when in fact I had lost") seems to separate problem/ pathological gamblers from non gamblers. 
Literature review reports that high incidents of relationship breakdowns are the result of deception, with spouses and intimate relationships to be affected mostly (Hodgins et al., 2007). Two more variables that seem to predict the progression from low-risk to high-risk gambling are Law issues (i.e. "I use to gamble when I worry about my debts"), and employment or school difficulties (i.e. "Sometimes, I have lost time from my work (or my school) due to my gambling"). This is consistent with previous research (Shaffer \& Hall, 2002). Finally, the last factor that emerged from regression analysis was that problem/ pathological gamblers would avoid eating more than non gamblers when engage in such behavior (i.e. Whenever I gamble, I usually forget to eat). There has been very little prior research concerning eating behavior that discriminates between pathological/ problem gamblers and non gamblers. In the present study, food avoidance was a crucial precipitating factor to gambling pathology. This finding must be replicated in further studies.

Although literature review is quite rich in early factors that play a crucial role in the onset of gambling behavior, some factors have not been studied excessively and should be taken into consideration for further research. For instance, no other studies have supported that trust - breaking behavior, lying and eating avoidance may be precipitating factors for gambling pathology. On the other hand, due to small sample size regression analysis must rerun in order to replicate more consistent findings.

CFA in psychological axis supports a five factor model that reflected dimensions of specific skills, way of thinking and self-control, lack of interceptive mechanisms and lying, perceived luck, behavioral - emotional state. Regarding specific skills the majority of cognitive bias is associated with games that involve an element of capacity (e.g. cards, betting on sports) (Toneatto et al., 1997; Myrseth et al., 2010). Gamblers that bet money on these games hold the erroneous belief that their abilities would crown the final positive outcome of the game. Way of thinking and self control of gamblers are supported in findings of previous studies. Gamblers that have had a big win early in their gambling history or have experienced many small wins at the beginning of their gambling behavior are more prone to develop a gambling disorder or cognitive distortions over their control on lucky games. Therefore, the loss of self control may cause chasing money (Caselli et al., 2013; Caselli \& Spada, 2011). Literature research has indicated that gamblers have lack of interceptive mechanisms and use lies in order to cover their gambling behavior. Impulsivity leads gamblers to focus on positive but not negative outcomes of gambling behavior. Gamblers in treatment try to diminish levels of their impulsivity but cannot control their desire for contentment and diversity. Therefore, these individuals score higher in impulsivity tests in relation to general population (Zuckerman, 1999; Blaszczynski et al., 1997; Castellani \& Rugle, 1995). Moreover, dysfunctional beliefs regarding luck are evident in problem gamblers in relation to social gamblers (Wohl et al., 2007). Finally, literature research has supported high frequency of emotional disorders such as anxiety or depressive disorders in pathological gamblers (Kim et al., 2006; el-Guebaly et al., 2006; Getty et al., 2000; 
Cunningham-Williams et al., 1998; Blaszczynski \& McConaghy 1989). Emotional disorders may either lead in gambling behavior or minimize the gambling symptoms (Kim et al., 2006).

CFA in biological axis supports a four factor model that reflected dimensions of pleasure (endogenous opioids), physiological responses, motives - reward seeking (dopamine) and anger - anxiety (cortisol). Regarding first factor, results are consistent with literature research. Alterations in opiodergic system lead an individual to an inability to control impulsive behavior due to intense euphoric emotions that experience when she/he deals with rewarding situations (Dackis \& O'Brien, 2005). Pathological gamblers experience chronic stress that leads in physiological responses such as hypertension, cardiovascular diseases, ulcer system diseases and aggravation of other medical problems (Natelson, 2004). The third factor is consistent with existing literature. It has been found a pre-existing reduced susceptibility to reward system associated with dopamine before the development of addictive behaviors. A predictable rewarding behavior do not stimulate phasic dopamine at the time of release (Fiorillo et al., 2003), while a sudden appearance of a neutral stimulus and unpredictable rewards stimulate phasic dopamine (Horvitz, 2000; Young et al., 1998). Pathological gamblers exhibit diminished reactions in rewards and losses and this may attributed to the reduced activation of mesolimbic prefrontal cortex during non - specific rewarding or punishing events (de Ruiter et al., 2009; Reuter et al., 2005), inducing the chase of large amounts of money from gambling.

Furthermore, anxiety can be either a risk factor in developing pathological gambling or a negative effect thereof (Zangeneh et al., 2008). High levels of heart rates have been reported in individuals following their participation in gambling (Krueger et al., 2005). Pathological gamblers have high levels of stress hormones (cortisol and activation of the HPA axis) compared with non-pathological players before the appearance of gambling disorder (Meyer et al., 2000; Meyer et al., 2004). Negative consequences of gambling produce feelings of anger and guilt while acute stress may lead in diminished appetite in pathological gamblers.

Finally, CFA in sociological axis supports a five factor model that reflected dimensions of attitudes towards gambling that Social Group \& Family Members hold, Social Policy, Couple and Family Relationships, Social Pressure, and Inability to cope with stressful situations. Regarding first factor, literature research indicates that pathological gamblers cope with higher percentage of divorces (Gerstein, 1999) while their obligations and activities are neglected. Reduced productivity of gamblers leads to reduced development opportunities as well as difficulties in their professional context and in key functional areas (Ladouceur et al., 1994). Gambling is easily accessible in western societies, increasing the rates of problematic gambling behavior (Ladouceur et al., 1999) and supporting the factor of social policy.

As regards couple and family relationships, recent literature supports that pathological gambling has pernicious results in the near environment of the player 
(Kalischuk et al., 2006), while gamblers in treatment often report family and fellow problems (Ladouceur et al., 2004). The more often reported problems of pathological players' partners are financial difficulties, feelings of guilt, accusations, anger, distrust, feeling of betrayal and communication problems, sexual dissatisfaction and difficulty in resolving conflicts (Dickson-Swift et al., 2005). Interpersonal conflicts, the quality of social support and attitudes of friends and family towards gambling are recurrent causes (Ledgerwood \& Petry, 2006).

Fourth factor that refers to social pressure is supported from many research studies. An individual gambles in order to socialize with others (Hope \& Havir, 2002). The more gambling behavior progresses, the more the time that the person spends with friends who gamble increases, leading to reduced close relationships with friends who do not gamble (Gupta \& Derevensky, 2000). Pathological gamblers bet more money on lucky games, smoke and use alcohol more with their friends compared to non pathological gamblers due to social adjustment (Meisel et al., 2012). Social norms and perceptions of significant others can influence the choices of individuals to engage in various risky behaviors (Welte et al., 2006). The pathological gambler tends to select gaming activities preferred by friends and members of his/her family (Delfabbro \& Thrupp, 2003; Martin et al., 2010; Welte et al., 2006).

Regarding fifth factor, the inability to cope with stressful situations, literature research indicates that pathological gamblers are more likely to borrow money from moneylenders or engage in illegal practices (Gerstein, 1999) while $30-40 \%$ of financial scandals (theft, embezzlement, insurance fraud, prostitution) come from pathological gamblers (Council, 1999). Social amplifiers provided by the casino (e.g. groups of members, emotional and moral support, self-esteem and social status) and the problems that the individual faces in everyday life lead to the continuation of gambling behavior (Ocean \& Smith, 1993). Problem gamblers experience a process of "double reinforcement", where social rewards act as positive amplifiers while the everyday problems that the gambler faces with society serve as negative amplifiers. Gambling problems are correlated with poor coping strategies (Sharpe \& Tarrier, 1993; Getty et al., 2000; Scannell et al., 2000; Shepherd \& Dickerson, 2001).

\section{Conclusion}

The present psychometric instrument provides a first step in self evaluation of problem and pathological gambling and aims at effective counseling and psychotherapeutic techniques seeking in order to reduce or even prevent addictive gambling behaviors. It is proposed for future studies to develop more specialised instruments that would assess particular domains of pathological gambling. In contrast with other psychiatric disorders, pathological gambling cannot be recognised through laboratory research. Nevertheless, neuroimaging studies could be carried out in order to control any variations in dopaminergic, serotonergic and noradrenergic system that have been found to be involved in the pathophysiology of the disorder, before, during and immediately after the gaming process. 
Findings from these observations in relation to this questionnaire could provide a fuller picture of the aetiology of the disorder and help experts to choose the appropriate therapeutic approach depending on the subscales the gambler notes higher rankings. Furthermore, depending on the subscale displayed to be increased, the individual would undergo further evaluations through questionnaires, blood tests or other methods in order to provide personalized and targeted treatment. This questionnaire can be used as a self-assessment tool in order to determine at risk and / or pathological gamblers and can be administered either in person or online.

There are a few minor limitations to the present study. The sample size of the study is considered relatively small. This questionnaire should be incorporated in a large scale population in order to reduce sampling error. The general sample of the study does not reflect a representative sample of the general population due to the fact that the study was conducted in Crete and the majority of participants were female, university students. Furthermore, the study used a cluster sample, and although they reported being 'regular gamblers', this sample may not be representative of a general population of adult gamblers. Also, a non-clinical sample may not generalize to a treatment sample. Thus, it would be useful to test this new measure in a more generalized and clinical sample. This would provide a more ecologically reliable sample and also could be used to examine the external reliability of the questionnaire.

Finally we wish to point out that the abovementioned questionnaire cannot be a static instrument. While it is ready for use now, secondary analysis and future studies may result in refinements to scoring and more inclusions or exclusions in the nonscored sections, particularly gambling involvement and the correlates sections.

\section{References}

Achab, S., Chatton, A., Khan, R., Thorens, G., Penzenstadler, L. E., Zullino, D. F. \& Khazaal, Y. (2014). Early Detection of Pathological Gambling: Betting on GPs' Beliefs and Attitudes. BioMed Research International, 2014: 1-7. http://dx.doi.org/10.1155/2014/360585

Afifi, T. O., Brownridge, D. A., MacMilan, H. \& Sareen, J., (2010). The relationship of gambling to intimate partner violence and child maltreatment in a nationally representative sample. Journal of psychiatric research, 44(5): 331-337. https://doi.org/10.1016/j.jpsychires.2009.07.010

American Psychiatric Association. (1994). Diagnostic and statistical manual of mental disorders, 4th ed. Washington, DC: Author.

Armitage, P. \& Berry, G. (1994). Statistical Methods in Medical Research. Oxford: Blackwell.

Beck, A. T. \& Beamesderfer, A. (1974). Assessment of depression: the depression inventory. Modern Problems of Pharmacopsychiatry, 7: 151 - 169.

https://doi.org/10.1159/000395074 
Bentler, P. M. (1990). Comparative fit indexes in structural models. Psychological Bulletin, 107 (2): 238 - 246. https://doi.org/10.1037/0033-2909.107.2.238

Ben-Tovim, D. I., Esterman, A., Tolchard, B. \& Battersby M. (2001). The Victorian Gambling Screen. Research Project. State of Victoria: Gambling Research Panel, Melbourne. [Google Scholar]

Bergen, A. E., Newby-Clark, I. R. \& Brown, A. (2012). Low Trait Self-Control in Problem Gamblers: Evidence from Self-Report and Behavioral Measures. Journal of Gambling Studies, 28:637-648. https://doi.org/10.1007/s10899-011-9274-9

Bergh, C., Eklund, T., Soedersten, P., \& Nordin, C. (1997). Altered dopamine function in pathological gambling. Psychological Medicine, 27 (2): 473-475. https://doi.org/10.1017/S0033291796003789

Black, D. W., Monahan, P. O., Temkit, M. \& Shaw, M. (2006). A family study of pathological gambling. Psychiatry Research, 141: 295-303.

https://doi.org/10.1016/j.psychres.2005.12.005

Blanco, C., Ibanez, A., Saiz Ruiz, J., Blanco-Jerez, C., \& Nunes, E. V. (2000). Epidemiology, pathophysiology and treatment of pathological gambling. CNS Drugs, 13 (6): 397-407. https://doi.org/10.2165/00023210-200013060-00002

Blaszczynski A. P. (2005). Conceptual and methodological issues in treatment outcome research. Journal of Gambling Studies, 21: 5-11. https://doi.org/10.1007/s10899-004-1916-8

Blaszczynski, A.P. \& McConaghy, N. (1989). The medical model of pathological gambling: Current shortcomings. Journal of Gambling Behavior, 5: 42-52. https://doi.org/10.1007/BF01022136

Blaszczynski, A., \& Nower, L. (2002). A pathways model of problem and pathological gambling. Addiction, 97: 487-499. https://doi.org/10.1046/j.1360-

$\underline{0443.2002 .00015 . x}$

Blaszczynski, A., \& Steel, Z. (1998). Personality disorders among pathological gamblers. Journal of Gambling Studies, 14: 51-71. https://doi.org/10.1023/A:1023098525869

Blaszczynski, A., Steel, Z., \& McConaghy, N. (1997). Impulsivity in pathological gambling: the antisocial impulsivist. Addiction, 92 (1): 75-87.

https://doi.org/10.1046/j.1360-0443.1998.93689511.x

Brand, M., Kalbe, E., Labudda, K., Fujiwara, E., Kessler, J., Markowitsch, H.J. (2005) Decision-making impairments in patients with pathological gambling. Psychiatry Res, 133: 91-99. https://doi.org/10.1016/j.psychres.2004.10.003

Browne, M. W., \& Cudeck, R. (1992). Alternative ways of assessing model fit. Sociological Methods and Research, 21(2): 230 - 258. https://doi.org/10.1177/0049124192021002005

Bullock, S. A., \& Potenza, M. N. (2012). Pathological gambling: neuropsychopharmacology and treatment. Current Psychopharmacology, 1: 6785. https://doi.org/ 10.2174/2211556011201010067. 
Byrne, B. M. (2000). Structural equation modeling with AMOS: basic concepts, applications and programming. Mahwah, New Jersey: Lawrence Erlbaum Associate.

Cardinal, R. N. (2006). Neural systems implicated in delayed and probabilistic reinforcement. Neural Networks, 19: 1277-1301.

https://doi.org/10.1016/j.neunet.2006.03.004

Carlton, P. L., \& Manowitz, P. (1994). Factors determining the severity of pathological gambling in males. Journal of Gambling Studies, 10 (2): 147-157. https://doi.org/10.1007/BF02109937

Caselli, G., \& Spada, M. M. (2011). The Desire Thinking Questionnaire: Development and psychometric properties. Addictive Behaviors, 36: 1061-1070. https://doi.org/10.1016/j.addbeh.2011.06.013

Caselli, G., Soliani, M., \& Spada, M. M. (2013). The effect of desire thinking on craving: An experimental investigation. Psychology of Addictive Behaviors, 27: 301-306. https://doi.org/10.1037/a0027981

Castellani, B., \& Rugle, L. (1995). A comparison of pathological gamblers to alcoholics and cocaine misusers on impulsivity, sensation-seeking, and craving. International Journal of the Addictions, 30(3): 275-289. https://doi.org/10.3109/10826089509048726

Chase, H.W. \& Clark, L. (2010). Gambling severity predicts midbrain response to nearmiss outcomes. Journal of Neuroscience, 30: 6180-6187. https://doi.org/10.1523/JNEUROSCI.5758-09.2010

Clark, L. A. \& Watson, D. (1995). Constructing validity: Basic issues in objective scale development. Psychological Assessment, 7: 309-319. https://doi.org/10.1037/1040-3590.7.3.309

Cohen, L., Manion, L. \& Morrison, K. (2008). Research methods in education (6th ed.). London \& New York: Routledge Taylor \& Francis Group.

Comings, D. E., Gade-Andavolu, R., Gonzales, N., et al. (2001) The addictive effect of neurotransmitter genes in pathological gambling. Clinical Genetics; 60: 107-16. https://doi.org/10.1034/j.1399-0004.2001.600204.x

Comrey, A. L. (1973). A first course in factor analysis. New York: Academic Press.

Comrey, A. L., \& Lee, H. B. (1992). A first course in factor analysis (2nd ed.). Hillside, NJ: Erlbaum.

Council, N.R. (1999). Pathological gambling: A critical review. Report to the National Gambling Impact Study Commission. Washington, DC: National Academy Press.

Cortina, J. M. (1993). What Is Coefficient Alpha? An Examination of Theory and Applications. Journal of Applied Psychology, 78(1): 98-104. https://doi.org/10.1037/0021-9010.78.1.98

Coventry, K. R., \& Brown, R. I. F. (1993). Sensation-seeking, gambling and gambling addictions. Addictions, 88: 541-554. https://doi.org/10.1111/j.13600443.1993.tb02061.x

Cunningham-Williams, R. M., Cottler, L. B., Compton III, W. M., Spitznagel, E. L. (1998). Taking chances: Problem gamblers and mental health disorders - Results from the 
St. Louis epidemiologic catchment area study American Journal of Public Health, 88 (7): 1093-1095. https://doi.org/10.2105/AJPH.88.7.1093

Dackis, C. \& O'Brien, C. (2005). Neurobiology of addiction: treatment and public policy ramifications. Nature Neuroscience, 8: 1431-1436.

https://doi.org/10.1038/nn1105-1431

de Ruiter, M. B., Veltman, D. J., Goudriaan, A. E., Oosterlaan, J., Sjoerds, Z., \& van den Brink, W. (2009). Response preservation and ventral prefrontal sensitivity to reward and punishment in male problem gamblers and smokers.

Neuropsychopharmacology, 34: 1027-1038. https://doi.org/10.1038/npp.2008.175

DeCaria, C. M., Begaz, T., \& Hollander, E. (1998). Serotonergic and Noradrenergic Function in Pathological Gambling. CNS Spectrum, 3(6):38-45. https://doi.org/10.1017/S1092852900006003

DeCaria, C. M., Hollander, E., Grossman, R., Wong, C. M., Mosovich, S. A., \& Cherkasky, S. (1996). Diagnosis, neurobiology, and treatment of pathological gamblers. Journal of Clinical Psychiatry, 57 (8): 80-84.

https://www.ncbi.nlm.nih.gov/pubmed/8698687

Delfabbro, P., \& Thrupp, L. (2003). The social determinants of youth gambling in South Australian adolescents. Journal of Adolescence, 26: 313-330. https://doi.org/10.1016/S0140-1971(03)00013-7

Dickerson, M. G. (1979). FI schedules and persistence at gambling in the UK betting office. Journal of Applied Behavioral Analysis, 12: 315-323. https://doi.org/10.1901/jaba.1979.12-315

Dickerson, M. G. (1993). Internal and external determinants of persistent gambling: problems in generalising from one form of gambling to another. Journal of Gambling Studies, 9 (3): 225-245. https://doi.org/10.1007/BF01015920

Dickerson, M., \& Baron, E. (2000). Contemporary issues and future directions for research into pathological gambling. Addiction, 95 (SUPPL. 2): 1145-1159. https://doi.org/10.1080/09652140050111087

Dickson-Swift, V. A., James, E. L. \& Kippen, S. (2005). The experience of living with a problem gambler: Spouses and partners speak out. Journal of Gambling Issues, 13: 1-22. http://dx.doi.org/10.4309/jgi.2005.13.6

Dimitriou, E. C. (1986). The Eysenck Personality Questionnaire (EPQ): The validity of the Greek adult and junior version. Encephalos, 23: 41 - 54

el-Guebaly, N., Patten, S. B., Currie, S., Williams, J. V. A., Beck, C. A., Maxwell, C. J., к $\alpha$ ı oUv., (2006). Epidemiological associations between gambling behaviour, substance use \& mood and anxiety disorders. Journal of Gambling Studies, 22: 275-287. https://doi.org/10.1007/s10899-006-9016-6

EL Hajjar, S. T. (2018). Statistical Analysis: Internal - Consistency Reliability and Construct Validity. International Journal of Quantitative and Qualitative Research Methods, 6 (1): 27-38.

Ely, J., Frankel, A. \& Kamenica, E. (2015). Suspense and surprise. Journal of Political Economy, 123(1): 215-260. https://doi.org/10.1086/677350 
Field, A. (2000) Discovering Statistics Using SPSS for Windows. London: Sage.

Field, A. P. (2013). Discovering statistics using IBM SPSS Statistics (4th ed ed). London: Sage Publications

Fiorillo, C. D., Tobler, P. N., \& Schultz, W. (2003). Discrete coding of reward probability anduncertainty by dopamine neurons. Science; 299:1898-902.

https://doi.org/10.1126/science.1077349

Fong, T., Kalechstein, A., Bernhard, B., Rosenthal, R., Rugle, L. (2008). A double-blind, placebo-controlled trial of olanzapine for the treatment of video poker pathological gamblers. Pharmacol Biochem Behav; 89: 298-303. https://doi.org/10.1016/j.pbb.2007.12.025

Fuentes, D., Tavares, H., Artes, R., Gorenstein, C. (2006) Self-reported and neuropsychological measures of impulsivity in pathological gambling. J Int Neuropsychol Soc, 12: 907-12. https://doi.org/10.1017/S1355617706061091

Garner, D. M. \& Garfinkel, P. E. (1979). The Eating Attitudes Test: an index of the symptoms of anorexia nervosa. Psychological Medicine, 9: $273-279$. https://doi.org/10.1017/S0033291700030762

Garner, D. M., Olmsted, M. P., Bohr, Y. \& Garfinkel, P. E. (1982). The Eating Attitudes Test: Psychometric features and clinical correlates. Psychological Medicine, 12: 871 - 878. https://doi.org/10.1017/S0033291700049163

Gerstein, D.R. (1999) Gambling Impact and Behavior Study: Report to the National Gambling Impact Study Commission. Chicago, IL: National Opinion Research Centre at the University of Chicago.

Getty, H. A., Watson, J. G., \& Frisch, R. (2000). A comparison of depression and styles of coping in male and female GA members and controls. Journal of Gambling Studies, 16: 377-391. https://doi.org/10.1023/A:3A1009480106531

Goudriaan, A.E., Oosterlaan, J., de Beurs, E., van den Brink, W. (2006). Neurocognitive functions in pathological gambling: a comparison with alcohol dependence, Tourette syndrome and normal controls. Addictiov, 101: 534-47. https://doi.org/10.1111/j.1360-0443.2006.01380.x

Gowing, L.R., Ali, R.L., Allsop, S., Marsden, J., Turf, E.E., West, R., Witton, J. (2015). Global statistics on addictive behaviors: 2014 status report. Addiction, 110: 904-19. https://doi.org/10.1111/add.12899

Griffin, P. (2005). Developing a measure of wealth for primary student families in a developing country: Comparison of two methods of psychometric calibration. Studies in Educational Evaluation, 31: 192-206 https://doi.org/10.1016/j.stueduc.2005.05.010

Gupta R., \& Derevensky J. L. (2000). Adolescents with gambling problems: from research to treatment. Journal of Gambling Studies, 16: 315-42 https://doi.org/10.1023/A:1009493200768

Hahn, C., Wilson, T. D., McRae, K. \& Gilbert, D. T. (2013). "Show me the money" vulnerability to gambling moderates the attractiveness of money versus 
suspense. Personality and Social Psychology Bulletin, 39(10): 1259-1267.

https://doi.org/10.1177/0146167213492431

Hand, I. (1998). Pathological gambling: A negative state model and its implications for behavioral treatments. CNS Spectrums, 3 (6): 58-71.

https://doi.org/10.1017/S1092852900006027

Hodgins, D.C., Schopflocher, D.P., el-Guebaly, N., Casey, D.M., Smith, G.J., Williams, R.J., Wood, R.T. (2010). The association between childhood maltreatment and gambling problems in a community sample of adult men and women.

Psychological Addiction Behavior; 24: 548-54. https://doi.org/10.1037/a0019946

Hodgins, D. C., Stea J. N., \& Grant J. E., (2011). Gambling Disorders. Published online, https://doi.org/10.1016/S0140-6736(10)62185-X

Hodgins, D.C., Toneatto, T., Makarchuk, K. (2007). Minimal treatment approaches for concerned significant others of problem gamblers: a randomized controlled trial. Journal of Gambling Studies, 23(2):215-230. https://doi.org/10.1007/s10899006-9052-2

Hollander, E., DeCaria, C. M., Mari, E., Wong, C. M., Mosovich, S., Grossman, R., \& Begaz, T. (1998). Short term single blind fluvoxamine treatment of pathological gambling. American Journal of Psychiatry, 155 (12): 1781-1783.

https://doi.org/10.1176/ajp.155.12.1781

Hollander, E., Frenkel, M., DeCaria, C., Trungold, S., \& Stein, D. J. (1992). Treatment of pathological gambling with clomipramine. American Journal of Psychiatry, 149:

710-711. https://doi.org/10.1176/ajp.149.5.710b

Hoorens, V. (1994). Unrealisitic optimism in health and safety risks. In: J., Chiu \& L., Storm, (eds). Personality, Perceived Luck and Gambling Attitudes as Predictors of Gambling Involvement. Journal of Gambling Studies, 2010; 26: 205-227. https://doi.org/10.1007/s10899-009-9160-x.

Hope, J., \& Havir, L. (2002) You bet they're having fun! Older Americans and casino gambling. Journal of Aging Studies, 16:177-97. http://doi.org/10.1016/S08904065(02)00043-9

Hu, L., \& Bentler, P. M., (1999). Cutoff criteria for fit indexes in covariance structure analysis: Conventional criteria versus new alternatives. Structural Equation Modeling: A Multidisciplinary Journal, 6(1): 1-55. https://doi.org/10.1080/10705519909540118

Ibanez, A., Blanco, C., de Castro, I.P., Fernández-Piqueras, J., \& Sáiz-Ruiz, J. (2003). Genetics of pathological gambling. Journal of Gambling Studies, 19(1):11-22. https://doi.org/10.1023/a:1021271029163

Jöreskog, K.G., (1969). A general approach to confirmatory maximum likelihood factor analysis. Psychometrika, 34: 183-202. https://doi.org/10.1007/BF02289343 Joukhador J, Blaszczynski A, Maccallum F. (2004). Superstitious beliefs in gambling among problem and non-problem gamblers: preliminary data. Journal of Gambling Studies, 20(2):171-80. https://doi.org/10.3109/10826089909039417 
Kalechstein, A.D., Fong, T., Rosenthal, R.J., Davis, A., Vanyo, H., Newton, T.F. (2007) Pathological gamblers demonstrate frontal lobe impairment consistent with that of methamphetamine-dependent individuals. J Neuropsychiatry Clin Neurosci, 19: 298-303. https://doi.org/10.1176/jnp.2007.19.3.298

Kalischuk, R. G., Nowatzki, N., Cardwell, K., Klein, K., \& Solowoniuk, J. (2006). Problem gambling and its impact on families: A literature review. International Gambling Studies, 6(1): 31-60. https://doi.org/10.1080/14459790600644176

Kim, S. W., Grant, J. E., Eckert, E. D., Faris, P. L., \& Hartman, B. K. (2006). Pathological gambling and mood disorders: Clinical associations and treatment implications. Journal of Affective Disorders, 92: 109-116.

https://doi.org/10.1016/j.jad.2005.12.040

Krueger, T. H. C., Schedlowski, M., \& Meyer, G. (2005). Cortisol and heart rate measures during casino gambling in relation to impulsivity. Neuropsychobiology, 52: 206-211. https://doi.org/10.1159/000089004

Ladouceur, R. (2004). Gambling: the hidden addiction. Canadian Journal of Psychiatry, 49(8):501-3. https://doi.org/10.1177/070674370404900801

Ladouceur, R., Boisvert, J.M., Pepin, M., Loranger, M. \& Sylvain, C. (1994). Social cost of pathological gambling. Journal of Gambling Studies, 10(4): 399- 409. https://doi.org/10.1007/BF02104905

Ladouceur, R., Jacques, C., Ferland, F., \& Giroud, I. (1999). Prevalence of problem gambling: a replication study 7 years later. Canadian Journal of Psychiatry, 44 802-804. https://doi.org/10.1023/A:1001986219288

Ladouceur, R., Sylvain, C., Se'vigny, S., Poirier, L., Brisson, L., Dias, C., et al. (2004). Caracte'ristiques des joueurs excessifs selon le mode de traitement. Que'bec: Universite' Laval. In: K., Bertrand, M., Dufour, J., Wright \& Lasnier B. (eds). Adapted Couple Therapy (ACT) for Pathological Gamblers: A Promising Avenue. Journal of Gambling Studies, 2008; 24:393-409. https://doi.org/10.1007/s10899-008-9100-1

Lambe, L., Mackinnon, S. P. \& Stewart, S. H. (2015). Validation of the gambling motives questionnaire in emerging adults. Journal of Gambling Studies, 31(3): 867-885. https://doi.org/10.1007/s10899-014-9467-0

Lawrence, A.J., Luty, J., Bogdan, N.A., Sahakian, B.J., Clark, L. (2009a). Impulsivity and response inhibition in alcohol dependence and problem gambling.

Psychopharmacology, 207: 163-72. https://doi.org/10.1007/s00213-009-1645-x

Lawrence, A. J., Luty, J., Bogdan, N. A., Sahakian, B. J., Clark, L. (2009b). Problem gamblers share deficits in impulsive decision-making with alcohol-dependent individuals. Addiction, 104: 1006-15. https://doi.org/10.1111/j.13600443.2009.02533.x

Ledgerwood, D. M., \& Petry, N. M. (2006). What do we know about relapse in pathological gambling? Clinical Psychology Review, 26: 216-228. https://doi.org/10.1016/j.cpr.2005.11.008

Ledgerwood, D. M., Alessi, S. M., Phoenix, N., \& Petry, N. M. (2009). Behavioral assessment of impulsivity in pathological gamblers with and without substance 
use disorder histories versus healthy controls. Drug and Alcohol Dependence, 105(1-2): 89-96. https://doi.org/10.1016/j.drugalcdep.2009.06.011

Lee, H. P., Chae, P. K., Lee, H. S. \& Kim, Y. K. (2007). The five-factor gambling motivation model. Psychiatry Research, 150(1): 21-32.

https://doi.org/10.1016/j.psychres.2006.04.005

Lesieur, H. R. \& Blume, S. B. (1987) The South Oaks Gambling Screen (SOGS): a new instrument for the identification of pathological gamblers. American Journal of Psychiatry, 144, 1184-1188. http://dx.doi.org/10.1176/ajp.144.9.1184.

Littman - Sharp, N., Turner N. E. \& Toneatto T., (2009). Inventory of Gambling Situations (IGS) User's Guide. Toronto: Centre for Addiction and Mental Health of Ontario (CAMH).

Lobo, D. S., Kennedy, J. L. (2009) Genetic aspects of pathological gambling: a complex disorder with shared genetic vulnerabilities. Addiction, 104: 1454-65. https://doi.org/10.1111/j.1360-0443.2009.02671.x

Lobo, D. S., Souza, R. P., Tong, R. P., et al. (2010). Association of functional variants in the dopamine D2-like receptors with risk for gambling behaviour in healthy Caucasian subjects. Biological Psychology, 85: 33-37. https://doi.org/10.1016/j.biopsycho.2010.04.008

Martin, R. J., Usdan, S., Nelson, S., Umstattd, M. R., LaPlante, D., Perko, M., et al. (2010). Using the theory of planned behavior to predict gambling behavior. Psychology of Addictive Behaviors, 24: 89-97. https://doi.org/10.1037/a0018452

McCormick, R. A., Taber, J. I., Kruedelbach, N., \& Russo, A. M. (1987). Personality profiles of hospitalised pathological gamblers: the California Personality Inventory. Journal of Clinical Psychology, 43 (5): 521-527. https://doi.org/10.1002/10974679(198709)43:5<521::AID-JCLP2270430516>3.0.CO;2-Q

McElroy, S.L., Nelson, E.B., Welge, J.A., Kaehler, L., Keck, P.E. (2008). Olanzapine in the treatment of pathological gambling: a negative randomized placebo-controlled trial. J Clin Psychiatry, 69: 433-40. https://doi.org/10.4088/jcp.v69n0314

Meisel, M. K., Clifton, A. D., MacKillop, J., Miller, J. D., Campbell, W. K., \& Goodie, A. S. (2012). Egocentric social network analysis of pathological gambling. Addiction, 108: 584-591. https://doi.org/10.1111/add.12014

Meyer, G., Hauffa, B.P., Schedlowski, M., Pawlak, C., Stadler, M. A., \& Exton, M. S. (2000). Casino gambling increases heart rate and salivary cortisol in regular gamblers. Society of Biological Psychiatry, 48(9):948-53. https://doi.org/10.1016/S0006-3223(00)00888-X

Meyer, G., Schwertfeger, J., Exton, M.S., Janssen, O.E., Knapp, W., Stadler, M.A., Schedlowski, M., Kruger, T.H. (2004). Neuroendocrine response to casino gambling in problem gamblers. Psychoneuroendocrinology, 29: 1272-1280. https://doi.org/10.1016/j.psyneuen.2004.03.005

Moreno, I., Saiz-Ruiz, J., Lopez-Ibor, J.J. (1991). Serotonin and gambling dependence. Human Psychopharmacology 6: 9-12. https://doi.org/10.1002/hup.470060503 
Myrseth, H., Brunborg, G. S., \& Eidem, M. (2010). Differences in cognitive distortions between pathological and non-pathological gamblers with preferences for chance or skill games. Journal of Gambling Studies, 26(4): 561-569.

https://doi.org/10.1007/s10899-010-9180-6

Natelson, B. H. (2004). Stress, hormones, and disease. Physiology \& Behavior 82(1):139-43. https://doi.org/10.1016/j.physbeh.2004.04.038

Nordin, C., \& Eklundh, T. (1999) Altered CSF 5-HIAA disposition in pathological male gamblers. CNS Spectrum, 4:25-33. https://doi.org/10.1017/S1092852900006799

Nordin, C., \& Sjodin, I. (2006). CSF monoamine patterns in pathological gamblers and healthy controls. Journal of Psychiatric Research, 40:454-459.

https://doi.org/10.1016/j.jpsychires.2005.06.003

Nower, L., Derevensky, J., \& Gupta, R. (2004). The relationship of impulsivity, sensation seeking, coping and substance use in youth gamblers. Psychology of Addictive Behaviors, 18(1): 49-55. https://doi.org/10.1037/0893-164X.18.1.49

Ocean, G., \& Smith, G. J. (1993). Social Reward, conflict, and commitment: a theoretical model of gambling behavior. Journal of Gambling Studies, 9(4): 321339. https://doi.org/10.1007/BF01014625

Oei, T.P. \& Raylu, N. (2004). Familial influence on off spring gambling: a cognitive mechanism for transmission of gambling behaviour in families. Psychological Medicine; 34: 1279-88. https://doi.org/10.1017/S0033291704003150

Oluwatayo, J. (2012). Validity and reliability issues in educational research. Journal of Educational and Social Research, 2: 391-400. https://doi.org/10.5901/jesr.2012.v2n2.391

Pallanti, S., Bernardi, S., Quercioli, L., DeCaria, C., \& Hollander, E. (2006). Serotonin dysfunction in pathological gamblers: increased prolactin response to oral $\mathrm{m}-\mathrm{CPP}$ versus placebo. CNS Spectrum, 11: 956-964. https://doi.org/10.1017/S1092852900015145

Petry, N. M. (2001) Pathological gamblers with and without substance use disorders, discount delayed rewards at high rates. Journal of Abnormal Psychology, 110: 482-87. https://doi.org/10.1037/0021-843X.110.3.482

Petry, N. M. \& Steinberg, K. L. (2005). Childhood maltreatment in male and female treatment-seeking pathological gamblers. Psychology of Addictive Behavior, 19: 226-29. https://doi.org/10.1037/0893-164X.19.2.226

Potenza, M.N. (2006) Should addictive disorders include non-substance-related conditions? Addiction, 101(1):142-51.

https://doi.org/10.1111/j.1360-0443.2006.01591.x

Potenza, M., Fiellin, D., Heninger, G., Rounsaville, B., Mazure, C. (2002) Gambling: An addictive behavior with health and primary care implications. Journal of General Internal Medicine, 17: 721-732. https://doi.org/10.1046/j.1525-1497.2002.10812.x

Potenza, M. N., \& Hollander, E. (2002). Pathological gambling and impulse control disorders. In J. Coyle, C. Nemeroff, D. Charney, \& K. Davis (Eds.), 
Neuropsychopharmacology: The 5th Generation of Progress p. 1725-1742. Baltimore, MD: Lippincott Williams and Wilkens.

Raylu, N. \& Oei, T. P. S. (2004). The Gambling Related Cognitions Scale (GRCS): development, confirmatory factor validation and psychometric properties. Addiction, 99: 757 - 769. https://doi.org/10.1111/j.1360-0443.2004.00753.x

Regard, M., Knoch, D., Gutling, E., Landis, T. (2003). Brain damage and addictive behavior: a neuropsychological and electroencephalogram investigation with pathologic gamblers. Cognitive and Behavioral Neurology, 16: 47-53. https://doi.org/10.1097/00146965-200303000-00006

Reuter, J., Raedler, T., Rose, M., Hand, I., Gläscher, J., Büchel, C. (2005). Pathological gambling is linked to reduced activation of the mesolimbic reward system. Nature Neuroscience; 8:147-148. https://doi.org/10.1038/nn1378

Roca, M., Torralva, T., Lopez, P., Cetkovich, M., Clark, L., Manes, F. (2008) Executive functions in pathologic gamblers selected in an ecologic setting. Cognitive Behavioral Neurology, 21: 1-4. https://doi.org/10.1097/WNN.0b013e3181684358

Russell, D. W. (2002). In search of underlying dimensions: The use (and abuse) of factor analysis in Personality and Social Psychology Bulletin. Personality and Social Psychology Bulletin, 28: 1629-1646. https://doi.org/10.1177/014616702237645

Saris, W. E. \& Gallhofer, I. (2007). Design, Evaluation, and Analysis of Questionnaires for Survey Research. New York: Wiley.

Scannell, E. D., Quirk, M. M., Smith, K., Maddern, R., \& Dickerson, M., (2000). Females' coping styles and control over poker machine gambling. Journal of Gambling Studies, 16: 417-432. https://doi.org/10.1023/A:1009484207439

Schreiber, L., Odlaug, B.L., Kim, S.W., Grant, J.E. (2009) Characteristics of pathological gamblers with a problem gambling parent. American Journal of Addiction; 18: 462-69. https://doi.org/10.3109/10550490903206007

Shaffer, H.J. \& Hall, M.N. (2002). The natural history of gambling and drinking problems among casino employees. The Journal of Social Psychology, 142 (4): 405-424. https://doi.org/10.1080/00224540209603909

Sharpe, L. (2002). A reformulated cognitive-behavioral model of problem gambling. A biopsychosocial perspective. Clinical Psychology Review, 22(1): 1-25. https://doi.org/10.1016/S0272-7358(00)00087-8

Sharpe, L. \& Tarrier, N. (1993). Towards a cognitive-behavioural theory of problem gambling. British Journal of Psychiatry, 162: 407-12.

https://doi.org/10.1192/bjp.162.3.407

Shaw, M. C. Forbush, K. T., Schlinder, J., Rosenman, E., \& Black, D. W. (2007). The effect of pathological gambling on families, marriages, and children. CNS Spectrum, August, 12(8), pp. 615-622. https://doi.org/10.1017/S1092852900021416

Shepherd, L., \& Dickerson, M., (2001). Situational coping with loss and control over gambling in regular poker machine players. Australian Journal of Psychology, 53: 160-169. https://doi.org/10.1080/00049530108255140 
Shinohara, K., Yanagisawa, A., Kagota, Y., Gomi, A., Nemoto, K., Moriya, E., Furusawa, E.., Furuya, K., Terasawa, K., (1999). Physiological changes in Pachinko players; betaendorphin, catecholamines, immune system substances and heart rate. Applied Human Science, 18:37-42. https://doi.org/10.2114/jpa.18.37

Slutske, W. S., Caspi, A., Moffitt, T.E. \& Poulton, R., (2005). Personality and Problem Gambling. A Prospective Study of a Birth Cohort of Young Adults. Archives of General Psychiatry. 62:769-775. https://doi.org/10.1001/archpsyc.62.7.769

Steel, Z., \& Blaszczynski, A. (1998). Impulsivity, personality disorders and pathological gambling severity. Addiction, 93 (6): 895-905. https://doi.org/10.1046/j.13600443.1998.93689511.x

Steeves, T.D., Miyasaki, J., Zurowski, M., Lang, A.E., Pellecchia, G., Van Eimeren, T., Rusjan, P., Houle, S., Strafella, A.P. (2009). Increased striatal dopamine release in Parkinsonian patients with pathological gambling: a [11C] raclopride PET study. Brain, 132: 1376-1385. https://doi.org/10.1093/brain/awp054

Steiger, J. H. (1990). Structural model evaluation and modification: An Interval Estimation Approach. Multivariate Behavioral Research, 25 (2): 173-180. https://doi.org/10.1207/s15327906mbr2502 4

Stevens, J. P. (1992). Applied multivariate statistics for the social sciences, (2nd edition ed). New Jersey: Erlbaum, Hillsdale.

Straub, D., Boudreau, M. C. \& Gefen, D. (2004). Validation guidelines for IS positivist research. Communications of the Association for Information Systems, 13: 380 427. https://doi.org/10.17705/1cais.01324

Sundqvist, K., Jonsson, J. \& Wennberg, P. (2016). Gambling motives in a representative Swedish sample of risk gamblers. Journal of Gambling Studies, 32(4): 1231-1241. https://doi.org/10.1007/s10899-016-9607-9

Toneatto, T. (1999) Cognitive psychopathology of problem gambling. Substance Use and Misuse, 34: 1593-1604. https://doi.org/10.1016/S1077-7229(02)80049-9

Toneatto, T., Blitz-Miller, T., Calderwood, K., Dragonetti, R., and Tsanos, A. (1997). Cognitive distortions in heavy gambling. Journal of Gambling Studies, 13, 253-261. https://doi.org/10.1023/A:1024983300428

Tzemos, J. (1984). The standardization of the Beck depression inventory in a Greek population sample. Medical School, University of Athens, Thesis.

Verdejo-Garcia, A., Lawrence, A.J., Clark, L., (2008). Impulsivity as a vulnerability marker for substance-use disorders: review of findings from high-risk research, problem gamblers and genetic association studies. Neuroscience Biobehavioral Review, 32: 777-810. https://doi.org/10.1016/j.neubiorev.2007.11.003

Vitaro, F., Arsenault, L., \& Tremblay, R.E. (1999). Impulsivity predicts problem gambling in low SES adolescent males. Addiction, 94: 565-575.

https://doi.org/10.1046/j.1360-0443.1999.94456511.x

Voon, V., Fernagut, P.O., Wickens, J., Baunez, C., Rodriguez, M., Pavon, N., Juncos, J.L., Obeso, J.A., Bezard, E., (2009). Chronic dopaminergic stimulation in Parkinson's 
disease: from dyskinesias to impulse control disorders. Lancet Neurol., 8: 11401149. https://doi.org/10.1016/S1474-4422(09)70287-X

Walters, G. D., 2001. Behavior genetic research on gambling and problem gambling: A preliminary meta-analysis of available data. Journal of Gambling Studies, 17(4), pp. 255-71. https://doi.org/10.1023/A:1013652328999

Welte, J. W., Wieczorek, W. F., Barnes, G. M., \& Tidwell, M. O. (2006). Multiple risk factors for frequent and problem gambling: Individual, social, and ecological. Journal of Applied Social Psychology, 36:1548-1568. https://doi.org/10.1111/j.0021-9029.2006.00071.x

Wohl, M. J. A., \& Enzle, M. E. (2003). The effects of near wins and losses on selfperceived personal luck and subsequent gambling behaviour. Journal of Experimental Social Psychology, 39: 184-191. https://doi.org/10.1016/S00221031(02)00525-5

Wohl, M. J. A., Young, M. M., \& Hart, K. E. (2007). Self-perceptions of dispositional luck: Relationship to DSM gambling symptoms, subjective enjoyment of gambling and treatment readiness. Substance Use and Misuse, 42: 42-63. https://doi.org/10.1080/10826080601094223

Young, A. M. J., Ahier, M. G., Upton, R. L., Joseph, M. H., Gray, J. A. (1998). Increased extracellular dopamine in the nucleus accumbens of the rat during associative learning of neutral stimuli. Neuroscience; 83: 1175-83. https://doi.org/10.1016/S0306-4522(97)00483-1

Zack, M., \& Poulos, C. X. (2004). Amphetamine primes motivation to gamble and gambling - related semantic networks in problem gamblers. Neuropsychopharmacology, 29:195-207. https://doi.org/10.1038/sj.npp.1300333

Zack, M. \& Poulos, C. X. (2007). A D2 antagonist enhances the rewarding and priming effects of a gambling episode in pathological gamblers. Neuropsychopharmacology; 32: 1678-86. https://doi.org/10.1038/sj.npp.1301295

Zangeneh, M., Grunfeld, A., \& Koenig, S. (2008). Individual factors in the development and maintenance of problem gambling. In M., Zangeneh, A., Blaszczynski, \& N. E., Turner (Eds.). In the pursuit of winning: Problem gambling theory, research and treatment (pp. 83-94). New York: Springer Science and Business Media._978-0387-72173-6 (Online)

Zhuravliova, I. (2010). Engaging in gambling as a psychosocial process in modern societies: the example of Greek society. (Phd Study), Athens: Panteion University, Department of Psychology.

Zuckerman, M. (1999). Vulnerability to psychopathology: a biosocial model. Washington, DC: American Psychological Association. In: N., Raylu \& T. P. S., Oei (eds.). Pathological Gambling: A comprehensive review. Clinical Psychology Review, 2002; 22: 1009 - 1061 https://doi.org/10.1016/S0272-7358(02)00101-0 


\section{Notes on Contributors}

Aikaterini Charonitaki is a Post Doc researcher in Laboratory of Social and Experimental Psychology, Panteion University. She holds a PhD in Psychology of Panteion University of Social and Political Sciences. She obtained a bachelor degree (Hons) in psychology from the University of Sunderland in 1999 and a master degree in counselling studies from the University of Durham in 2000. She works as an adjunct professor at Hellenic Mediterranean University at School of Health and Welfare Services, Nursing Department, where she teaches the modules: "Introduction to Psychology", "Counseling \& Communication in Nursing", "Health Psychology" She has worked as an adjunct professor at the department of Nutrition and Dietetics, in Sitia, Greece, where she taught the modules: "Psychology and Psychopathology of Nutrition", "Introduction to Psychology" and "Nutrition and Educational Counselling". Her current research interests include the psychosociology of addiction and rehabilitation in gambling disorders.

Irina Zhuravliova is a Post Doc Researcher in Laboratory of Virtual Reality and Internet Research and Education, Department of Psychology, School of Social Sciences (Panteion University). She holds a Phd degree in Psychology of Panteion University of Social and Political Sciences. She obtained a bachelor degree (Hons) in psychology from the National University of Athens and a master degree in Organizing and Economic Psychology at Panteion University of Social and Political Studies. She has also obtained a Bachelor Degree in English language and literature from Kiev National Linguistic University (KNLU), Ukraine.

Konstantinos Koskinas is a Professor of Sociology and Director of the Laboratory of Virtual Reality, Internet Research and E-Learning at the Dpt of Psychology (Panteion University). He teaches socio-psychology and political socio-psychology of virtual communities, methodology of online research, cyber-politics and cyber-culture, internet and humanities. He has long and extensive experience of national, EU-level and international project management and participation, along with numerous academic publications and conference presentations on the impact of ICT and virtual technologies on online and offline human life and interaction. Moreover, he has a vest research interest in how and under what conditions physical (actual) reality can (or will) converge with digital /cyber reality forming new social spaces, relationships and connections, thus creating new fields of exploration for the social scientists. 